\title{
Platelets, Photosensitizers, and PDT
}

\section{Mathias O. Senge Dr. rer. nat., FTCD ${ }^{\text {a,b, }}{ }^{*}$, Marek W. Radomski M. D., D. Sc., FTCD, Dhc ${ }^{\text {c }}$}

a Medicinal Chemistry, Institute of Molecular Medicine, Trinity Centre for Health Sciences, Trinity College Dublin, St James's Hospital, Dublin 8, Ireland

b School of Chemistry, SFI Tetrapyrrole Laboratory, Trinity Biomedical Sciences Institute, 152-160 Pearse Street, Trinity College Dublin, Dublin 2, Ireland

c School of Pharmacy \& Pharmaceutical Sciences, Trinity College Dublin, Dublin 2, Ireland

\footnotetext{
${ }^{*}$ Corresponding author at: School of Chemistry, SFI Tetrapyrrole Laboratory, Trinity Biomedical Sciences Institute, 152-160 Pearse Street, Trinity College Dublin, Dublin 2, Ireland

E-mail address: sengem@tcd.ie (M.O. Senge).
}

KEYWORDS

Vasculature; Photodynamic therapy; Photosensitizers; Platelets; Porphyrins; Cancer; Endothelial cells

\section{Summary}

Photodynamic therapy (PDT) has both direct cell and indirect vascular effects. Both are well established and the latter has given rise to specifically target angiogenesis in PDT treatments. While the vascular effects are well understood, further advances in antiangiogenesis require a detailed understanding of PDT effects at the microvasculature level. Although some of the earliest investigations of PDT noted effects on platelet aggregation the importance of their interaction with endothelial cells and the crucial role of various signaling pathways is only now emerging. This review aims to give a general overview of PDT related studies on platelets, vascular effects, and their interaction with endothelial cells to indicate the potential for studies in this area.

Abbreviations: ALA - $\delta$-aminolevulinic acid; AMD - age-related macular degeneration; ANET - anti-neovascular therapy; BGF - basic fibroblast growth factor; DHE dihaematoporphyrin ether; EDRF - endothelium-derived relaxing factor; epithelial growth factor - EGF; HIF-1 $\alpha$ - hypoxia-inducible factor $1 \alpha$; HpD - haematoporphyrin derivative; IL - interleukin; PAF - platelet activating factor; PDT - photodynamic therapy; PS - photosensitizer; transforming growth factor $\beta 1$ - TGF- $\beta 1$; TNF - tumor necrosis factor. 


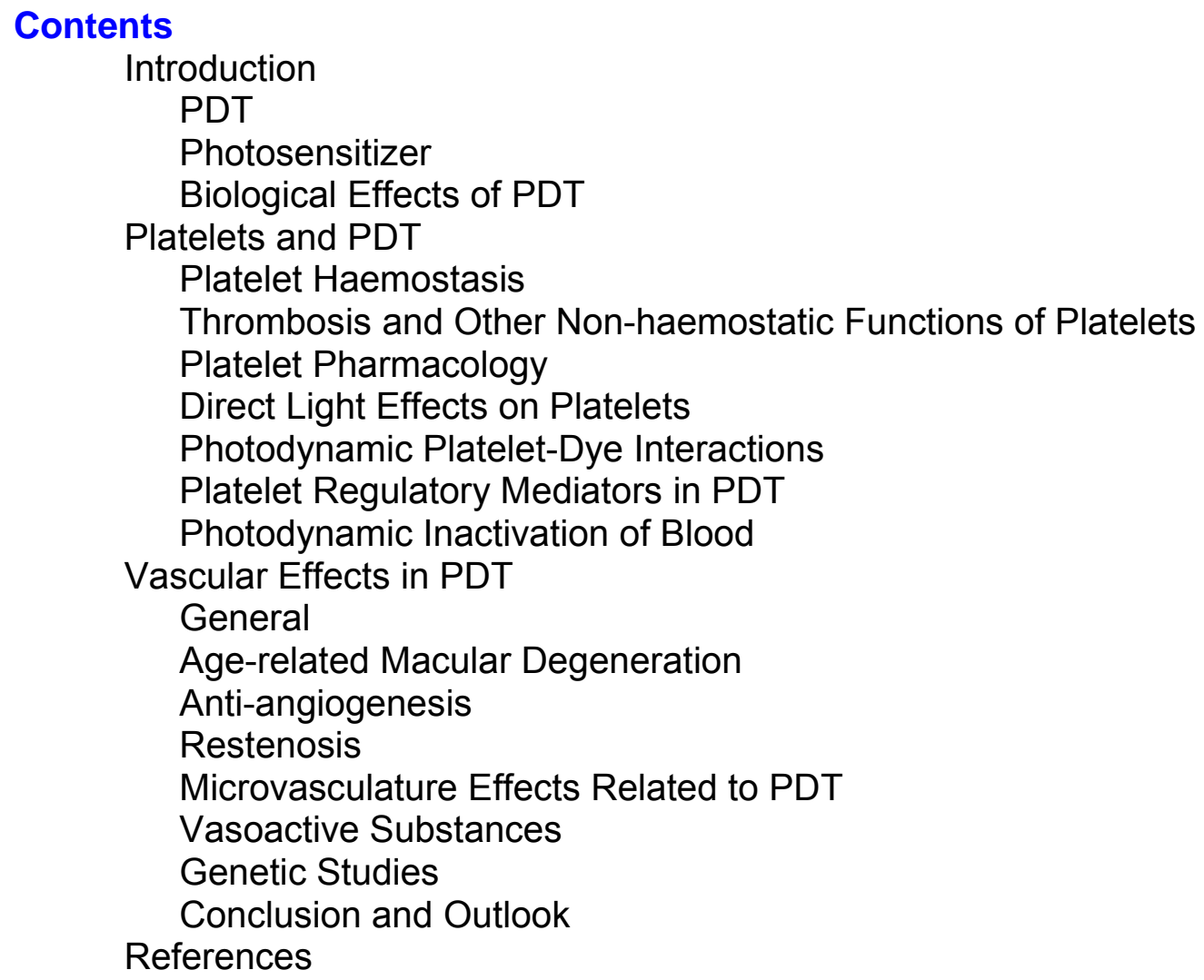




\section{Introduction}

PDT

Photodynamic therapy (PDT) is a simple, nonsurgical modality for the treatment of malignancies and dysplasias and has found applications in cancer therapy and indication, dermatology, cosmetics and disinfection. It is based on the biological effects that result form the photosensitized generation of singlet oxygen in the target material. Historically, its origins lie with the groundbreaking work on sensibilizing dyes by Raab [1] and Finsen [2] and in the initial studies on porphyrins by Meyer-Betz [3], followed by initial in vitro experiments in the Thirties and Forties of the last century $[4,5,6]$. Contemporary research in this area started with initial observations by Schwartz [7] and Lipson et al. [8] and began in earnest in the 1970ties with the works of Kessel and Dougherty $[9,10]$. It requires only two reactants: a) a dye capable of generating singlet oxygen, a so-called photosensitizer and b) light.

The first step of PDT involves uptake of dyes into the target tissue, preferentially with selective enrichment over healthy tissue and porphyrins feature prominently in this area [11]. Upon exposure of the tissue with visible light the photosensitizer and ambient (triplet) oxygen generate singlet oxygen in a photochemical reaction (type II reactions). Alternatively, formation of reactive oxygen species through electron transfer reactions is possible, too (type I reactions) [12]. Singlet oxygen then acts as the pharmacological agent and promotes direct cell necrosis and apoptosis. Singlet oxygen has a very short life-time and thus its generation is controlled by the presence of the photosensitizer and the applied light [13]. Hence, this modality is especially suited for treatment of localized tumors or dysplasias, e.g. skin cancers or endoscopically accessible areas, e.g., the gastrointestinal tract [14]. Most attention has been focused on the use of PDT for the treatment of malignancies [15]. Thus, the clinical target is the eradication of the tumor tissue. This can be achieved through direct cell action, immunological effects and angiogenesis.

\section{Photosensitizers}

A large number of photosensitizing dyes have been studied in PDT. Chemically, the only requirement for a "good" PS is a high quantum yield for singlet oxygen formation and appropriate solubility. Solubility in water is not necessarily a requirement, as many "delivery vehicles", such as liposomes, dendrimers, bioconjugates and nanocarriers have been developed for PS $[16,17]$.

Chemically most of the photosensitizing dyes used are porphyrins and other tetrapyrroles. However, other classes of compounds such as anthraquinones and phenothiazines are suitable as well $[18,19]$. A well studied example for a nonporphyrin OS is hypericin $\left(4,5,7,4^{\prime}, 5^{\prime}, 7^{\prime}\right.$-hexahydroxy-2,2'-dimethylnaphthodianthrone) [20]. These drugs differ widely in their solubility, stability, lipophilicity and intracellular targeting. Nevertheless, the individual choice of a PS for clinical studies is more dependent on what PS is available to the clinicians, comprehensive studies of several PS by one group are rare. In the context of our discussion here, especially the lipophilicity of the 
PS is important. Serum components play an important role in the transport of lipophilic $P S$ and thus can influence vascular effects significantly.

Figure 1 shows a selection of the more actively investigated PS. Currently, the main PS in clinical use are:

- Haematoporphyrin derivative: The oldest PS in clinical use. Chemically it is a mixture of ether and ester linked oligomers with $n$ up to 9 (see Fig. 1) [21,22]. Trade names are Photofrin $®$ while the active component is called porfimer sodium. It was first approved in Canada for bladder cancer and is now FDA approved for esophageal cancer, endobronchial and early stage cervical cancer and high-grade dysplasia in Barrett's esophagus.

- 5,10,15,20-Tetra(3-hydroxyphenylchlorin): Often abbreviated as mTHPC, also called Temoporfin. Tradenames of different formulations are: Foscan $®$, Fospeg $\circledast$, Foslip $\circledR$. Clinically approved in Europe for the treatment of head and neck cancer $[23,24]$.

- $\delta$-Aminolevulinic acid: Abbreviated as ALA. ALA is the biosynthetic precursor of heme, thus the intracellularly active substance is endogenously formed protoporphyrin IX. Trade names are Levulan $®$, Metvix® (for methyl aminolevulinate) and Hexvix ${ }^{\circledR}$ (Europe) or Cysview ${ }^{\circledR}$ (USA) (hexaminolevulinate). Levulan is FDA approved for acticinic keratosis and has orphan drug status for esophageal dysplasia. Metvix is approved in many countries for the treatment of non-melanoma skin cancer. Hexvix is used as an imaging agent for bladder cancer $[25,26]$.

- Benzoporphyrin derivative monoacid ring $A$ : Drug name: Verteporfin $®$, Trade name: Visudyne ${ }^{\circledR}$, Approved for treatment of age-related macular degeneration [27,28], although treatment with the monoclonal antibody fragment Ranibizumab or Bevacizumab today appears to be superior $[29,30]$.

- Mono-L-aspartyl chlorin $e_{6}$ : Synonyms: Talaporfin®, NPe6. Approved in Japan under the trade name Laserphyrin ${ }^{\circledR}$ for treatment of lung cancer.

Many others are under investigation and in various phases of clinical investigations. To name only a few: Antrin, Photochlor, Radochlorin, Texaphyrin (Motexafin), Photosens, Purlytin, azadipyrromethenes, silicon phthalocyanine PC-4, and others [31]. A notable compound is Tookad®, a $\mathrm{Pd}(\mathrm{II})$ bacteriopheophorbide a derivative, which specifically targets the vascular system using short drug-light intervals $[32,33]$. 


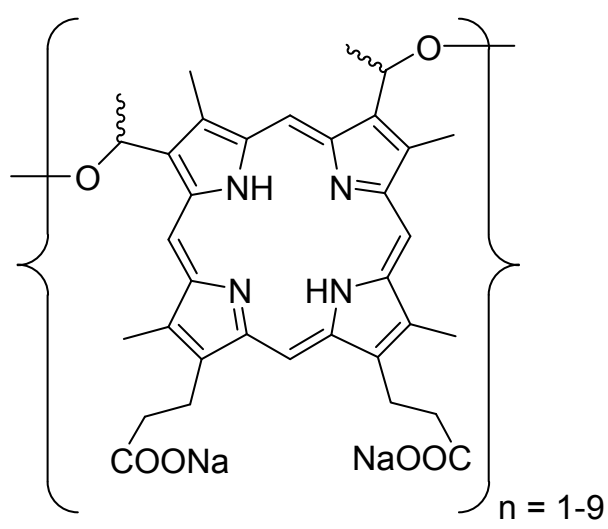

Haematoporphyrin derivative $=$ Photofrin

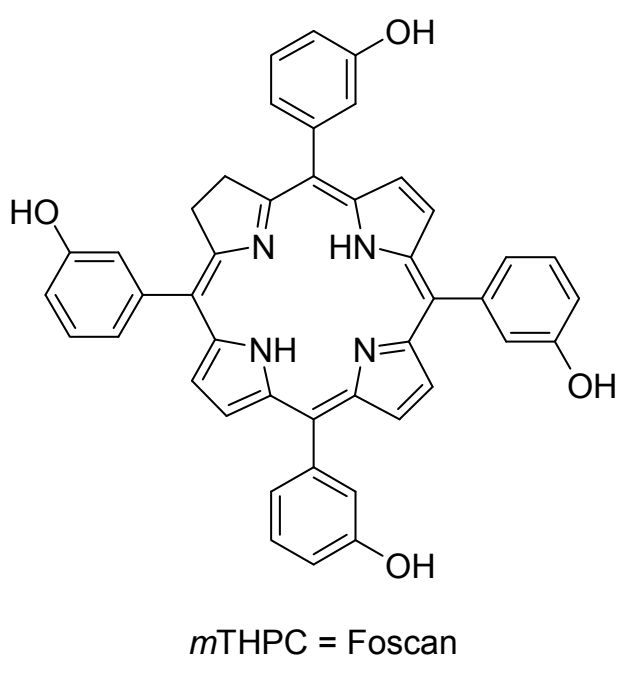<smiles>NCC(=O)CCC(=O)O</smiles>

$\mathrm{ALA}=\delta$-aminolevulinic acid

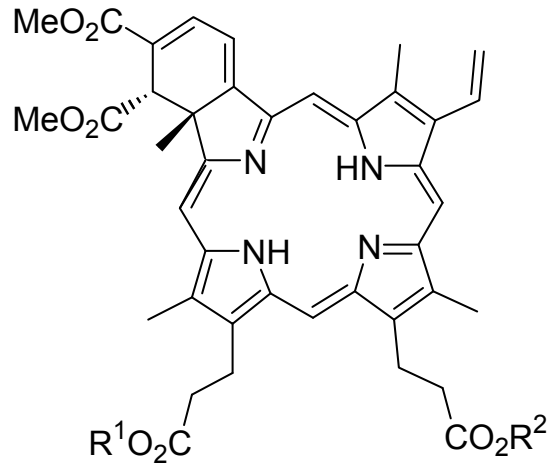

benzoporphyrin derivative Verteporfin

regioisomeric mix of $\mathrm{R}^{1}=\mathrm{H}, \mathrm{R}^{2}=\mathrm{Me}$

$\mathrm{R}^{1}=\mathrm{Me}, \mathrm{R}^{2}=\mathrm{H}$<smiles></smiles>

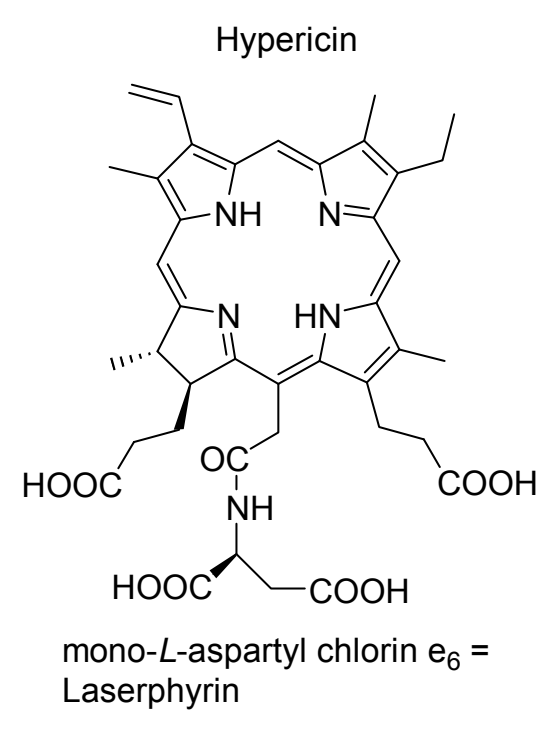

Figure 1. Selected photosensitizers in clinical use. 


\section{Biological Effects of PDT}

The biological effects of PDT encompass a multitude of effects, many of which are interconnected. At the subcellular level, PDT effects are especially noted on membranes, but also on cell surfaces, lysosomes, mitochondria and other cell organelles. Direct effects on DNA have been noted, and DNA and RNA polymerase inhibition has been shown. However, these effects are repairable to a significant extend.

Individual cell death effects depend on the cell line, the PS type and sometime the rate of cell growth and its physical manifestation, e.g. the size of cell clusters. Both necrosis and apoptosis result from PDT. Depending on the PS the relative effects of necrosis versus apoptosis vary and no clear cut answer can be derived from clonogenic cell survival curves [34]. Simple dose-response analyses are difficult to perform and to compare as uptake, photophysics (singlet oxygen quantum yield) and photodynamic action depend not only on the drug and cell type but also the light conditions (flux, wavelength, rate, etc.).

Photodynamic effects vary drastically with the cell type. Early on, it was realized that different cell type show widely varying susceptibility to PDT. The noted PDT effect on different cells can vary from report to report, and direct comparisons can be difficult due to different light regimes, analytical methods, incubation times, and so on. Nevertheless, overall, vascular endothelia commonly appear to be the most sensitive cell type when compared to tumor cells or normal fibroblasts or smooth muscle cells [35].

The in vivo situation is even more complicated, as there are direct and delayed effects that result in tumor destruction. Likewise, different repair mechanism and a more rapid recovery of healthy tissue compared to other treatment modalities play a role. Significantly, vascular effects play a major role in PDT. All effects are strongly affected by regulators of inflammation, blood flow, vessel tone, and biochemistry [36]. These regulators control also the function of human platelets.

\section{Platelets and PDT}

\section{Platelet Haemostasis}

Platelets are anucleated, discoid and approximately $2 \mu \mathrm{m}$ in size blood elements that derive via fragmentation of large mother cells, megakaryocytes [37]. They play a crucial role in regulation of vascular homeostasis and haemostasis by controlling the integrity of vascular wall as well as blood fluidity. Under physiological shear stress conditions the endothelial cells release potent inhibitors of platelet activation including prostacyclin and nitric oxide (NO). The synergistic interactions between these mediators prevent platelet activation and maintain platelets in the quiescent state $[38,39]$. Platelets have the capacity to release NO, thus contributing to the overall platelet regulation [40].

When the vascular integrity is compromised as a result of accidental injury adhesion proteins may be presented to the flowing blood. Platelets can adhere to the damaged fragments of the vascular wall using specific set of ligands (e.g., von Willebrand factor or collagen) adhesion receptors such as glycoprotein GPIb. When the 
activation stimuli persists platelets progress form aggregates to reinforce loose plateletvessel wall structures. The formation of platelet aggregates proceeds via activation of the major platelet receptor, glycoprotein GPIIb/IIla and GPIIb/IIla-dependant binding of fibrionogen. Finally, the subsequent reinforcement of the primary plug with fibrin stabilizes the structure and seals the vascular rent [37]. The generation and release of platelet mediators such as thromboxane $A_{2}$, adenosine diphosphate and matrix metalloproteinase-2 contributes to the stabilization of platelet aggregates [41].

\section{Thrombosis and Other Non-haemostatic Functions of Platelets}

Thrombosis is a pathological extension of haemostasis and strikes when the balance between the inhibitor and stimulator actions of platelet regulators is disturbed [37]. The endothelial dysfunction brought about by vascular diseases such as hypertension, diabetes mellitus or atherosclerosis exemplifies such scenario [42]. In addition to thrombosis, platelets play a role in two processes very relevant to PDT, i.e. inflammation and carcinogenesis.

The interactions of platelets with leukocytes taking place following the engagement of platelet P-selectin receptor with its counter receptor on leukocytes, Pselectin glycoprotein ligand-1 (PSGL-1) lead to formation of mixed aggregates and provides a link between inflammation and thrombosis [43].

Tumour cell-induced platelet aggregation (TCIPA) represents yet another example of heterotypic platelet-cancer cell interactions [44]. The biological relevance of this process lies in platelet-sponsored increase in cancer cell survival in response to anticancer treatment, stimulation of blood-borne metastasis, invasion and angiogenesis $[45,46,47,48]$.

\section{Platelet Pharmacology}

The significance of platelet-derived factors in the pathogenesis of vascular diseases is underscored by huge pharmacological relevance of platelet inhibitors such as aspirin, ADP-receptor antagonists or thrombin inhibitors [49,50,51]. Interestingly, aspirin, the most common platelet inhibitor has been found to confer population benefits for cancer prevention [52]. Despite the overall importance of platelet effects for vascular health and disease and multitude of physiological, pathological and pharmacological data there are only very few papers that directly address questions of the role of platelets in PDT.

\section{Direct Light Effects on Platelets}

Even light in the absence of externally added PS can affect the function and biochemistry of platelets. Best known is perhaps the effect of UV light, which can act as a direct stimulus for platelet aggregation. This effect is enhanced in the presence of extracellular fibrinogen and can be inhibited by several agents [53]. This effect is distinct from photodynamic action or photosensitization although the possibility exists that similar reactive species are involved. 
Light induced platelet aggregation has also been observed, at least indirectly, in a cat model. Studies in the early 1980ties used cat pial microvessels and upon intravenous injection of sodium fluorescein and UV-light filtered Hg-light exposure and revealed platelet aggregation, vacuole formation, luminal membrane rupture and swelling of the nuclear envelope [54]. Laser irradiation has also been used as a model for platelet related vascular injury $[55,56]$. Any studies relating photochemical action to direct intervention with platelets or other blood components, has to take their optical properties into account [57]. Likewise, photochemolysis of Human red blood cells can occur and the resulting release of hemoglobin will affect the penetration depth of the activating laser light [58].

Upon treatment of platelet-rich plasma under conditions similar to phototherapy significant changes were observed in platelet function, biochemistry and morphology [59]. Platelets became unable to aggregate and exhibited a loss of ADP, ATP and glycogen. Electron microscopy showed features reminiscent to those shown in Figure 2. These effects could be enhanced upon addition of hematoporphyrin as a PS. Studies in rabbits showed that the platelet turnover is significantly enhanced upon phototherapy. In low birth weight infants phototherapy was said to result in significantly lowered platelet counts [60]. However, contradictory reports exist [61]. Related studies showed no significant differences in platelet count and platelet factor 4 level [62]. Similarly, no evidence was found for light-induced oxidative stress during phototherapy in newborns [63]. A recent study on in full term neonates with indirect hyperbilirubinemia reported a statistically significant increase in platelet count after phototherapy [64]. However, the increase was only $1 / 9^{\text {th }}$ of the esd. Clearly, more studies are warranted in this area.

\section{Photodynamic Platelet-Dye Interactions}

The impact of light and photodynamic dyes on platelet function has been known for a long time. At the same time as Lipson et al. reported on cancer PDT [8]. Zieve et al. studied the effects of light on platelets in detail [65]. Using hematoporphyrin and a $1000 \mathrm{~W}$ light bulb for irradiation they elucidated the resulting morphological, functional and biochemical changes in Human platelets. The platelets exhibited loss of cytoplasm and a rounded, smooth contour (Fig. 2). Notably, they did not aggregate upon addition of thrombin and $\mathrm{CaCl}_{2}$. A light-dependent loss of serotonin and ATP was observed as well. The uptake of hematoporphyrin was dependent upon the light regime and the $\mathrm{pH}$. PDT treated platelets showed increased dye uptake compared to control cells; no uptake occurred at $4{ }^{\circ} \mathrm{C}$ [66]. Platelets also exhibited a PDT-dependent depletion of potassium and acid phosphatase [67]. 

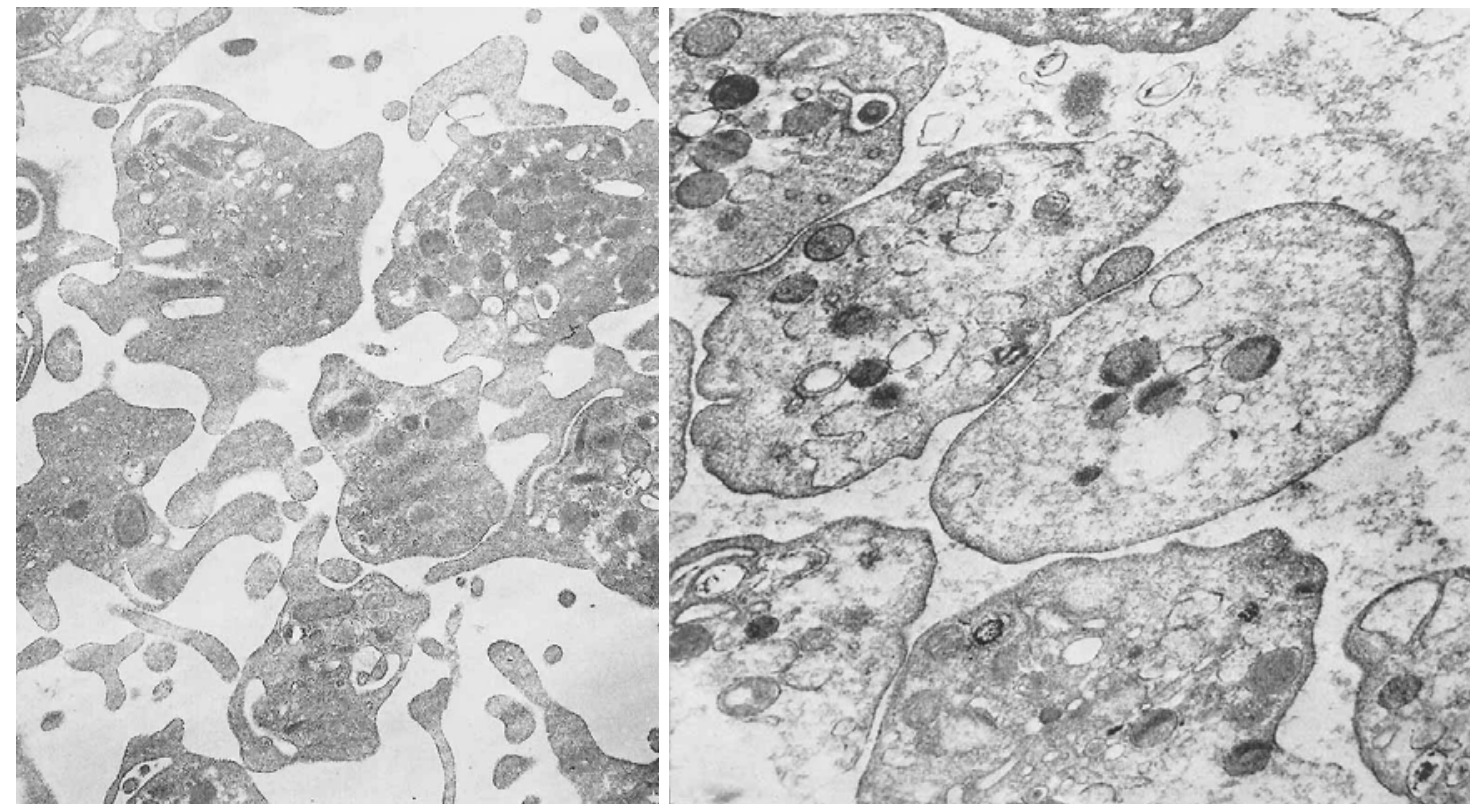

Figure 2. Platelets treated with hematoporphyrin $(0.67 \mathrm{X} \mathrm{M})$ and exposed to light for ten minutes at $37{ }^{\circ} \mathrm{C}$. Magnification $\times 30,000$. Left: control platelets. Reproduced with permission from ref. [65].

Similar results were obtained with an electron microscopic and serological analysis of the platelets derived from $\mathrm{HpD}$ treated normal mice showed that platelet necrosis proceeds rapidly with almost all platelets were necrotized after $8 \mathrm{~h}$. Even directly after irradiation some platelets exhibited swelling and deformation [68]. Similarly, PDT-related erythrocyte damage has been shown to be light-dependent [69].

A detailed study on direct PDT effects on platelets was published in 1992 by Henderson et al. [70]. Using isolated human platelets and endothelial cells they showed that exposure to Photofrin and light resulted in a rapid loss of the ability to aggregate. At high concentrations Photofrin also exhibited an inhibitory effect in the absence of light. Similarly, endothelial cells released prostacyclins upon exposure to Photofrin or phthalocyanine PS and light, which was linked to plasma membrane damage. This effect could be prevented through indomethacin administration. Endothelial cells also release significant amounts of arachidonic acid and prostaglandin F2 [71] upon PDT. This study clear demonstrated that the in vitro effect (anti-thrombogenic) is opposite to the in vivo effect (platelet aggregation) of PDT on the vascular system. Phenothiazinium based photosensitizers have also been used and shown to directly damage platelets [72].

\section{Platelet Regulatory Mediators in PDT}

Clearly many signaling substances such as NO or effectors such as singlet oxygen directly affect the platelet biochemistry. Many of these aspects have been outlined above. However, only few studies address specific PDT-induced platelet effects. 
One such study investigated the effect of PDT treated extracellular matrix proteins on platelet adhesion. For this, extracellular matrix [73], fibrinogen, von Willebrand factor, and collagen I and III were treated with a solution of Photofrin, illuminated by $630 \mathrm{~nm}$ light and then platelet aggregation was investigated with perfusion experiments [74]. PDT pretreatment significantly lowered platelet adhesion to the extracellular matrix, fibrinogen and von Willebrand factor. In the latter mostly the A1, $A 2$ and A3 domain but not the D'-D3 domains were affected. In contrast, platelet aggregation was drastically enhanced with PDT treatment of collagen. Clearly, PDT alters the platelet binding potential of adhesive proteins. The correlation of this effect with the collagen content of vessels indicates that large arteries (low collagen content) should become less thrombogenic upon PDT while veins and arterioles (high collagen content) should be more susceptible to thrombus formation. Thus, a specific targeting of the microvasculature using PDT is possible.

Singlet oxygen as the chemically active species of PDT has been shown to affect many components of hemostasis [75]. These include inactivation of various factors (fibrinogen, V, VIII, von Willebrand, X, plasminogen activator inhibitor I, antiplasmin- $\alpha 2$ ). It results in a downregulation of thrombocyte function and an upregulation of polymorphonuclear granulocytes. The latter has been linked to the increased expression of the Mac-1 (CD11b/CD18) receptor via PDT [76]. Chemically the photooxidation of fibrin and plasminogen aids their cleavage. Nevertheless, many of these studies used in vitro experiments and need to be confirmed in vivo. Still an emerging body of information points to singlet oxygen being a significant intracellular effector and regulator. In addition, there are indications that the deactivation of secondary oxidants in Human serum resulting from exposure to ${ }^{1} \mathrm{O}_{2}$ is affected by the serum type and number of platelets [77].

An intriguing recent development came from studies on artheriosclerosis. Standard cardiovascular drugs such as atorvastatin, a 3-hydroxy-3-methylglutarylcoenzyme A reductase inhibitor, and clopidogrel, a platelet adenosine diphosphate receptor antagonist to inhibit platelet aggregation, both having antioxidant effects, were found to interfere with the cytolytic effects of photodynamic therapy on macrophages (murine macrophage Raw 264.7 cells) in vitro [78]. Aspirin had a much smaller effect.

Another putative regulatory aspect relates to the platelet activating factor (PAF). Production of this factor and PAF receptor agonists (glycerophosphocholines) can be induced by UV-B radiation. This is believed to be one cause of skin cancer through systemic immunosuppression. Experiments with Human epidermal KB cells revealed elevated level of reactive oxygen species and PAF receptor agonists. This effect could be counteracted by vitamin $\mathrm{C}$ and inhibitors of the epidermal growth factor receptor [79].

\section{Photodynamic Inactivation of Blood}

The photodynamic killing of microorganism, although the oldest application of PDT, is again slowly gaining momentum. Obvious targets are antifungal actions, disinfection, oral sterilization and more [80]. A reasonably well established application worth mentioning in our context is the pathogen eradication in blood supplies [19]. Toluidine blue and methylene blue have been used for a long time and the latter is used in industrial applications for the disinfection of plasma [81]. A chemically demethylated 
derivative (thionin) has been developed for platelet decontamination [82]. Clearly the latter, and the decontamination of erythrocytes $[83,84,85,86]$, presents more of a challenge than simple disinfection of plasma. Recently, studies on the photodynamic inactivation of white blood cells in red blood cell products have been published, too [87]. In correlation with lower hematocrit content the T-cell proliferation could be decreased. Additionally, changes in cell surface antigen expression and the cellular cytokine profiles were noted.

\section{Vascular Effects in PDT}

\section{General}

The vascular effects of PDT have been discussed in many reviews over the years $[88,89]$. Briefly, three main aspects need to be considered here. These are inflammation processes, changes in vascular permeability and conformation, e.g., vasoconstriction, and finally vessel occlusion. Ultimately this results in tissue hypoxia as one means of tumor destruction. The three aspects are clearly interlinked and can be affected by vasoactive substances and a clear understanding requires investigations at the microvascular level.

At the inflammatory and immune level it is clear by now that many regulatory molecules influence the endothelial biochemistry and the blood flow and vessel structure [90]. Individual effects depend on drug and light doses and also include changes in the gene expression and regulation. The situation is complicated as the different biochemistry of tumor tissue often includes changes in the regulatory pathways, which need to be taken into account. Overall, PDT causes acute inflammation, upregulates the expression of heat-shock proteins, promotes the infiltration of tumors by immune system cells amongst other effects. Next to vasoactive substances, this is affected by the release of interleukins and tumor-necrosis factor. This is opposite to the effects of radio- and chemotherapy and surgery which are immunosuppressive [91]. However, recent reports on non melanoma skin cancer ALA treatment have indicated that PDT induced immunosuppression can occur and can be prevented by using lower light doses [92].

Without going too much into the details only a few benchmark studies can be mentioned here. One aspect concerns the pronounced neutrophilia elicited by PDT. For example Photofrin PDT of mouse EMT6 tumors revealed a cornucopia of affected mediators. These included complement fragments and secondary mediators such as cytokines IL-1b, IL-6, IL-10, TNF- $\alpha$, thromboxane, prostaglandins, leukotrienes, histamine, coagulation factors, G-CSF, the mouse analogue of GRO- $\alpha(\mathrm{KC})$ and others [93].

Clearly, the permeability of the vascular system will influence the drug uptake. Questions such as improved retention of PS in tumor versus normal tissue or the lack thereof must be addressed and it is well established that PDT results in significant changes in the structure and permeability of blood vessels. The most significant result of this is vasoconstriction. The latter is in part a result of changes in the endothelium, e.g., a lower production of the EDRF. Likewise, vasoactive substances such as prostaglandins, leukotrienes, or thromboxanes must be considered when studying the 
effects of PDT. For example, in vivo studies showed increased levels of vasoactive eicosanoids in conjunction with PDT-induced tumor regression, an effect which could be counteracted by eicosanoid inhibitors. Vessel occlusion is the result of thrombus formation and could be delayed or prevented by aspirin. The kinetics of this process differ significantly from PS to PS and release of the von Willebrand factor has also been implicated in this effect. These "tissue effects" are important in a conceptional sense as they allow the treatment of larger tumors through hypoxia, despite the limited tissue penetration of the activating light. Even a rudimentary analysis of these processes clearly implicates platelets and their aggregation as one of the key steps in these effects.

In the context of the present topic the sequence of PDT-related effects may be summarized as outlined by van den Bergh [94]: i) (partial) internalization of the PS by endothelial cells, ii) photodynamic action and generation of ${ }^{1} \mathrm{O}_{2}$, iii) rounding of endothelial cells, widening of interendothelial cell junctions and exposure of the vascular basement membrane; iv) increase of vascular permeability and release of clotting and vasoconstricting factors, v) platelet adherence to damaged cell walls and thrombus formation, vi) hemostasis and tissue hypoxia as a result.

It must also be considered that the vascular versus cellular compartment distribution of a PS depends on the incubation time and the properties of a given PS. In a rough approximation, a PS first enters the vascular system and only with time diffuses from the vessels into the tissue. Thus, it is possible to specifically target PDT towards the vascular system using short drug-light intervals.

An illuminating study addressed the question of the different angiogenic responses of short versus long drug-light intervals using hypericin PDT of a human bladder carcinoma xenograft model [95]. Immunohistochemical results indicated that angiogenic proteins such as VEGF, TNF- $\alpha$, interferon- $\alpha$, and basic fibroblast growth factor were overexpressed after long drug-light intervals for cellular targeting. Likewise, the gene expression of adhesion molecules such as cadherin 5, collagen $\alpha 1$ and $\alpha 3$ was downregulated. Clearly, anti-angiogenic drugs must be included in the treatment when targeting intracellular PDT. Intriguingly, TNF- $\alpha$ preconditioning was recently shown to aid in cryosurgical tumor treatment through vascular mechanisms via promotion of inflammation and neutrophil recruitment [96]. Similarly, animal studies with BPD-A showed the relevance of leukocyte recruitment for increase permeability of microvessels for drugs and water. This mechanism is different from direct endothelial photodamage and involves leukocyte attraction and activation in a complex mechanism [97].

Similar concepts also relate to circumventing the lowered oxygen availability in PDT-treated tissue due to tissue hypoxia. Here the hypoxia-inducible factor $1 \alpha$ (HIF-1 $\alpha$ ) may present a new target [98]. HIF-1 $\alpha$ is a transcription factor which regulates angiogenesis, hematopoeisis, and the energy metabolism. Ji et al. showed that the chemically induced overexpression of HIF-1 $\alpha$ resulted in an increased resistance of Het-1A esophageal cancer cells to ALA PDT [99]. Likewise, a knock out of the HIF-1 $\alpha$ expression using anti-HIF-1 $\alpha$ siRNA reinstated the photosensitivity of the cells. Thus, hypoxia-induced HIF-1 $\alpha$ overexpression modulates the PDT efficacy not only through angiogenesis but through cellular resistance as well. 


\section{Age-related Macular Degeneration}

The photodynamic treatment of age-related macular degeneration (AMD) presents perhaps the best established example of using photodynamic vascular effects in medicine. Most applications in this area apply to the treatment of choroidal neovascularization in AMD [30,94,100]. Vascular PDT targets the endothelial cells resulting in the release of regulatory factors and alterations in the cytoskeleton which may affect cell shape. This is believed to "interrupt interendothelial cell tight junctions, reduce interendothelial cell communication, and expose the subendothelial basement membrane" [94]. As clotting factors are released the circulating platelets are activated, adhere to the basement membrane, form aggregates, and lead to vessel closure. This is confirmed by many experimental studies. E.g., an electron microscopic study on the Verteporfin PDT effects on choroidal and retinal structures in the hum eye clearly showed swelling, shrinking and fragmentation of the choriocapillary endothelium, basement detachment, and ultimately thrombus formation [101]. Similar results were obtained with a liposomal formulation of a (phthalocyaninato)zinc(II) derivative [102]. Likewise, Ghazi et al. described in a case report the ultrastructural changes upon treatment of subfoeval choroidal neovascularization and noted endothelial cell degeneration, platelet aggregation, and thrombus formation [103].

In fact, the Verteporfin-induced photodynamic angioocclusion in capillaries could be followed in real time in a chorioallantoic chick embryo membrane model [104]. Platelet aggregation could be monitored directly and platelets were found to accumulate at intravascular junctions within seconds after light treatment. It took only 5 min for small vessel occlusion to occur at clinically relevant drug and light doses. The same model was also used to investigate the sequence of vascular events after PDT. Studying the regrowth of capillaries in PDT treated areas, it was found that $24 \mathrm{~h}$ post PDT new blood vessels emerge. Unique endothelial structures appear to guide the vessels towards the treatment center and reperfusion of vessel closed by PDT occurred. More detailed investigations showed that substances such as Vb3-integrin, vimentin and galectin-1, which are markers for angiogenic blood vessels, are enhanced in the treated area. In contrast, an endothelial maturation marker (intercellular adhesion molecule ICAM-1) was suppressed. Thus, angiogenesis occurs after PDT [105].

\section{Anti-angiogenesis}

Next to direct cell killing and the shutdown of the blood and oxygen supply to existing tumor tissue tumor, angiogenesis presents another target for cancer therapy [106]. Angiogenesis involves the formation of new blood vessels and anti-angiogenic therapy, in principle, is believed to circumvent many of the side effects of classic cancer chemotherapy. Potentially, targeting angiogenesis also allows a suppression of tumor metastases. Recent years have seen the emergence of an intriguing new treatment modality, the so-called anti-neovascular therapy (ANET). The aim is to directly and selectively target the angiogenic vasculature in the tumor and thus to destroy newly formed blood vessels. Next to benefits in minimizing drug-resistance, this clearly is an area that calls for PDT. In fact, much of the past photodynamic AMD treatments could be labeled as ANET-PDT, as uncontrolled angiogenesis is one hallmark of AMD [106]. 
Consequently, Kurobane et al. showed that a liposomal formulation of benzoporphyrin derivative monoacid PDT can be used to target the angiogenic vasculature [107]. Using a murine dorsal air sac model and a Meth A sarcoma mouse model they found evidence that direct targeting of the neovasculature is possible and can result in strong tumor suppression. A key aspect here was the use of polycationic liposomes for targeting [108] and both in vivo and in vitro photocytotoxic effects against endothelial cells were found. Initial results point towards induction of apoptosis in the endothelial cells [109].

Earlier studies with hypocrellin PDT of gliomas, macrophage and endothelial cell lines showed a complex pattern for the release of many (anti-)angiogenic factors [110]. Thus, the proangiogenic VEGF and the antiangiogenic sFlt-1, angiostatin, p43, allograft inflammatory factor-1 and connective tissue growth factor were all induced. In the gliomas cells thrombospondin-1 release was lower, while endostatin release was enhanced after PDT, while the latter was reduced in macrophages and endothelial cells. Clearly, optimum PDT therapy requires a careful balancing act of all factors involved [99].

Interestingly, platelets represent a rich reservoir of proangiogenic and antiangiogenic factors and are involved in cancer angiogenesis [111]. Moreover, the balance between these regulator factors can be pharmacologically altered and lead to modulation of angiogenesis [46,112].

Therefore, reducing angiogenesis by inhibition of proangiogenic and stimulation of antiangiogenic factors may be an attractive strategy for a multimodality approach in PDT. For example, the coadministration of anti-angiogenic monoclonal antibodies such as avastin or erbitux in a bladder tumor mouse model showed that a targeting of both VEGF and EGFR in conjunction with hypericin PDT resulted in a more rapid PDT response [113].

\section{Restenosis}

Another possible application of PDT relates to the prevention of restenosis. Luminal narrowing of vessels (vascular stenosis) results from various vessel wall diseases such as atherosclerosis. This narrowing is treated with balloon catheters followed by insertion of stent [114]. The procedure induces injuries to the vessel wall that are repaired by various physiological processes that include smooth muscle proliferation of the intima (intimal hyperplasia). Restenosis is the phenomenon that occurs at such places as a result of proliferation and migration of smooth muscle cells. Drug releasing stents are an effective means for treatment in this area [115]. However, the long term effects are unclear and bypassing the need for cytostatic drugs or invasive modalities would be beneficial [116]. Interestingly, smooth muscle migration and proliferation can be targeted specifically by PDT agents [117]. Likewise, arteriosclerosis has been targeted by PDT with motexafin lutetium with some success in animal studies but is not used clinically [118].

Restenosis can be inhibited by both PDT and $\beta$ - or $\gamma$-radiation. PDT clearly offers an advantage here as it does not induce teratogenic effects and results in more divers effects [119,120,121]. Current studies often employ liposomal formulations or hydrophobic drugs which can bind to LDLs [117]. For example, photoangioplasty has 
been suggested as a potential treatment modality as it reduces or inhibits restenosis [122]. Similarly, a texaphyrin derivative has been used to target athermomatos plaque and was suggested as a means to treat vein graft disease [123].

Several experimental studies underpin this treatment approach. For example, it could be shown using balloon-injured rat carotid arteries and a phthalocyanine PS that significant endothelial lining occurred three days post PDT. This effect persisted for up to 30 days [124]. Supporting information was obtained with a porcine restenosis model [125]. A study using collagen type I matrix gels and human fibroblasts showed that the fibroblast proliferation can be significantly impaired via methylene blue PDT. This was accompanied by a reduction in the basic fibroblast growth factor (bFGF) and the transforming growth factor $\beta 1$ (TGF- $\beta 1$ ) at the mRNA level [126].

\section{Microvasculature Effects Related to PDT}

A detailed understanding of the vascular effects requires investigations at the microvascular level $[127,128]$. Early on changes PDT-related changes in the microvasculature were noted. These included platelet aggregation and thrombus formation and resulted in vessel shutdown [129,130]. This could be related to the release of vasoactive substances (see below). Overall, platelet effects must be set in the context of changes in endothelial cells. Endothelial cells release vascular mediators as a response to many external stimuli and PDT is not exception here. The crucial role of oxygen radicals in the signaling cascades and complement activation was established even before related studies on PDT effects were initiated [131].

One of the first studies on alterations in the microcirculation was performed by Reed et al. in 1988 [132]. Using in vivo television microscopy of the normal rat cremaster they investigated the PDT effect of dihaematoporphyrin ether (DHE) on paired and unpaired arterioles and venules. Irradiation with either blue $(450-490 \mathrm{~nm})$ or green $(530-560 \mathrm{~nm})$ light resulted in a reduction of the blood flow of all vessels. Together with the formation and embolization of platelet thrombi, this gave $80 \%$ stasis of arterioles and $90 \%$ stasis of venules. After $2 \mathrm{~h}$ only the arterioles showed $20 \%$ reperfusion but not the venules. This reduction in the blood flow was attributed to vasoconstriction and platelet thrombus formation. The magnitude of these effects depended on the incident light energy. Platelet aggregation can also be adhesion initiated by ionizing radiation [133].

One of the earliest effects of PDT on the microvasculature is granulocyte adhesion. Using human umbilical vein endothelial cells as an in vitro model, Photofrin PDT in the presence of neutrophils led to drastic changes in the cell morphology. Neutrophil adherence to the subendothelial matrix was observed in a drug dose and illumination time dependent manner. This process could be inhibited by anti- $\beta_{2}$-integrin antibodies, low temperature $\left(4{ }^{\circ} \mathrm{C}\right)$, or staurosporin pre-incubation [134]. The central role of neutrophils in PDT was clearly proven in a rat study, where the PDT efficacy correlated with the number of neutrophils [135].

PDT induced microvascular damage to endothelial cells has been observed for many photosensitizers. These include uro-, copro- and protoporphyrin, with the lipophilic protoporphyrin IX clearly being most active [136]. Likewise, blood flow stasis was shown for ALA [137] and has been discussed for borylated porphyrins [138]. For Laserphyrin 
PDT in mice with Meth-A tumor microscopic studies revealed the formation of emboli as a result of platelet aggregation containing fibrin to be the dominant microvascular change [139]. This effect was dose and light dependent [140]. PDT also inactivates the matrix associated transforming growth factor $\beta$ (TGF- $\beta$ ) [141]. This results in rapid reendothelialization, has been used in experimentally inhibit intimal hyperplasia [142], and may help in post treatment healing [143]. Newer PS also allow the direct targeting of endothelial cells. Bechet et al. utilized a chlorin PS carrying a heptapetide targeting neuropilin-1 in Human malignant glioma xenografted mice [144]. A significant tumor growth delay was found and related to a $50 \%$ reduction in tumor tissue blood flow and was accompanied by the induction of tissue factor expression and resultant thrombus formation.

Another interesting study used sulfonamide derivatives of porphycene. Using human umbilical vein endothelial cells in Matrigel it was shown that the photosensitizer prevents the formation of the capillary-like network [145]. Similarly, two ALA-PDT resistant mammary adenocarcinoma cell lines exhibited a significantly decreased ability to invade Matrigel [146]. Other examples are a reduction in micro vessel density in a HT-29 human colon cancer xenograft model as a result of treatment with SN-38-loaded chlorin-core star block copolymer micelles [147].

More detailed studies were performed with chrondrosarcoma bearing rats. Photofrin was administered and $30 \mathrm{~min}$ prior to light treatment throbytopenia was induced using rabbit anti-rat platelet antibodies. As a result the circulating platelet level dropped from 300000 to $20000 \mathrm{~mm}^{-3}$. No changes in vessel constriction and blood flow stasis were observed upon PDT [148]. Thus, platelets and eicosanoid release are necessary for PDT induced vessel constriction. Studies with MV6401 in a mammary tumor revealed a biphasic antivascular response of PDT. The acute response involved vasoconstriction but no thrombus formation. Thrombus formation was only observed during the long term response (past $3 \mathrm{~h}$ ) [149].

Advances in optical technologies make it possible to today study the PDT effects at the level of an individual vessel. Wilson and coworkers showed that intravital imaging with confocal microscopy in conjunction with Doppler optical coherence tomography can be used to monitor the blood flow in a single blood vessel [150]. Using a variety of fluorescent labels the platelet aggregation and the damage to endothelial cells could be followed dynamically.

\section{Vasoactive Substances}

Clearly vasoactive substances are affected by PDT. A radioimmunoassay study using rats with chondrosarcoma tumor and Photofrin showed a dose-response relationship between the amount of photosensitizer, light-dose and thromboxane release into the serum. Light treatment gave higher levels of thromboxane from tumor tissue than tumor-free tissue. No PDT effect on the release of prostacyclin was found. Interestingly, coadministration of indomethacin suppressed the thromboxane release and the PDT-induced vascular stasis and tumor death [151,152]. Likewise, administration of the thromboxane A2 antagonist SQ29548 significantly delayed the platelet thrombus formation in arterioles and venules [153]. More detailed studies of the same biological system studied the effects of R68070 (thromboxane synthetase 
inhibitor), SQ29548, and flunarizine (inhibitor of platelet shape change) [154]. SQ29548 resulted in a $50 \%$ decrease of thromboxane levels, while no thromboxanes were detected with the other two inhibitors. Vessel constriction was completely prevented by flunarizine and reduced by SQ29548 or R68070. The latter two also inhibited vessel permeability while flunarizine did not. The PDT tumor cure was significantly reduced by these inhibitors in all animals.

On the other hand aspirin appeared to have a repair effect. Treatment of rats with chloroaluminum sulfonated phthalocyanine accompanied by aspirin administration $(0.1$ or $10 \mathrm{mg} \cdot \mathrm{kg}^{-1}$ ) immediately before, immediately after, and $6 \mathrm{~h}$ post PDT showed that high doses of aspirin given post PDT resulted in no PDT-induced vascular response [155]. The chorioallantoic membrane model has been used for many studies in this area. Aspirin administration in conjunction with PDT has been shown to be able to maximize the vascular permeability and leakage at an early stage thus potentially allowing a minimizing of inflammatory and angiogenic responses [156].Several studies have addressed the use of aspirin together with PDT for the treatment of choroidal neovascularization. A review of clinical data for 222 patients treated during 2001-2004 was performed by Ranchod et al. [157]. For patients taking aspirin more PDT treatments were required. On the other hand Löw et al. found no evidence for a negative effect of aspirin in a cohort of 60 patients [158].

Clearly, the endothelium-derived relaxing factor (EDRF), which is a vasodilator and platelet aggregation inhibitor, must play a major role in these effects. A PDT study with Photofrin in Wistar rats studied the endothelium-dependent thoracic aorta relaxation and found a decrease upon PDT treatment in a light- and drug-dose dependent manner. Thus PDT appeared to limit the production or release of EDRF by the endothelium [159].

Similarly, cytokines can affect the sensitivity of endothelial cells to PDT. A study of bovine pulmonary artery endothelial cells and chloroaluminum sulfonated phthalocyanine showed that pretreatment with fibroblast growth factor (FGF), transforming growth factor $\beta$, and to some extent interleukin-1 $\alpha$ enhanced the PDT effect. No such effect was observed with tumor necrosis factor $\alpha$ or platelet-derived growth factor (PDGF) [160].

Epithelial growth factor (EGF) presents another interesting target. In vitro experiments with gliomas cell lines and $\mathrm{HpD}$ showed that prePDT treatment with EGF had no effect, while postPDT treatment decreased the toxicity [161]. Similarly, pretreatment with EGF, basic fibroblast growth factor, or PDGF had not effect on ALA or proto IX PDT in glioma cells [162].

Hypericin is a useful test bed drug as it primarily targets the tumor vasculature. Thus PDT results in increased expression of proangiogenic factors, especially vascular endothelial growth factor (VEGF). Studies with a nasopharyngeal carcinoma xenograft model showed that VEGF levels were higher after shorter drug-light intervals ( $1 \mathrm{vs}$. $6 \mathrm{~h}$ ). The VEGF levels could be lowered when the angiogenesis COX-2 inhibitor Celebrex was used in conjunction with PDT [163]. Likewise use of hypericin in a bladder cancer model was shown to elicit the formation of arachidonic acid by phospholipase $A_{2}$. Inhibition of this enzyme results in the activation of p38 MAPK an upregulator of COX-2 and survival signal. Inhibition of this regulator blocked the release of VEGF and shut 
down tumor-promoted endothelial cell migration [164]. Again, this points to the potential of anti-angiogenic and dual treatment strategies.

An example for such an approach was investigated by Allen et al. [165]. Many known integrin receptors bind the Arg-Gly-Asp (RGD) motif and soluble RGD peptides have been shown to induce apoptosis at high concentrations in cell lines. Adjuvant RGD treatment under PDT conditions with a (phthalocyaninato)aluminum derivative in adenocarcinoma lung cancer cells (A549) or EMT6 murine mammary cancer cells counteracted the apoptotic PDT effect at low RGD concentrations. This indicates that unambiguous information about the details of the regulatory pathways is necessary for optimized PDT treatments.

Singlet oxygen also affects the extracellular signal regulated kinase $1 / 2$ (ERK) and the Akt/protein kinase $B$ pathways in Human dermal fibroblasts. While phosphorylation of the former was lowered by ${ }^{1} \mathrm{O}_{2}$ the latter was moderately activated [166]. Intracellular PDT with Rose Bengal inhibited the EGF or PDGF initiated activation of both pathways.

If vasoconstriction lowers the blood supply to the tumor tissue this clearly negatively impacts PDT due to the lowered availability of oxygen. Hence suppression of coagulation might improve the PDT results. Use of heparin as an anti-coagulant in a mammary carcinoma (EMT6) mouse model confirmed this [167]. The control group with PDT + heparin exhibited reduced thrombosis, better light delivery, improved perfusion, and oxygen supply, all resulting in improved tumor responses. The coagulation process of endothelial cells is regulated by thrombomodulin and tissue factor. Phthalocyanine PDT in Human umbilical vein endothelial cells altered the thrombogenic state by lowering the expression of thrombomodulin and by increasing the tissue factor levels [168].

With so many different vasoactive regulators involved it will be no surprise that $\mathrm{NO}$ must be considered here as well. NO has been implicated in PDT action for some time, however, experimental studies have only emerged in recent years [169]. Nitric oxide influences oxidative stress, vascular processes and leucocytes, all of which are strongly affected by PDT. NO can act as a vasodilator, counteracts platelet aggregation and adhesion to the endothelium, hinders the aggregation of neutrophils and lowers the extravasation of circulating leukocytes $[39,169]$. Thus, growing attention is focused on nitric oxide's overall role in the cancer outcome. Clearly, modalities that involve oxygen and reactive species thereof must be considered here [9].

The principle importance of NO in Photofrin PDT was established in fundamental studies by Korbelik's and Henderson's groups [170,171,172]. Inhibition of nitric oxide synthase increased the PDT efficacy of murine tumors in a fluence rate dependent manner [171]. Experimentally these studies utilized the administration of $N_{x}-n i t r o-L-$ arginine (and its methyl ester) as nitric oxide synthase inhibitors. A comparison of a high NO producing cells (RIF-1 and SCCVII) and low NO producers (EMT6 and FsaR) showed that only the former gave a better therapeutic outcome [170]. Thus, the exact PDT outcome depends on the cell type, administration of the inhibitor before or after PDT and the light regime used. Note, that high NO producing tumor cells are resistant to standard PDT (e.g., RIF-1). Such systems exhibit increase macromolecular leakage and vasoconstriction upon nitric oxide synthase inhibition and PDT. These effects did not occur in low NO producers (EMT6) [173]. 


\section{Genetic Studies}

In the case of verteporfin PDT for age-related macular degeneration treatment pharmacogenetic studies are available that further strengthen the important role of regulatory pathways. One aspect of this is thrombophilia, an increased tendency towards thrombosis. Genetic factors appear to play a major role in adjusting the balance between procoagulant and anti-coagulant mechanism. Based on initial observations in variations in the PDT outcome of Caucasian versus Asian patients it seems opportune to investigate the coagulation-balance genetic backgrounds with regard to PDT effectiveness.

For example, methylenetetrahydrofolate reductase $\mathrm{C} 677 \mathrm{~T}$ substitution results in a better subfoeval choroidal neovascularization response to PDT. C677T is a common thrombophilic folate pathway genotypic polymorphism [174]. Likewise, a statistical analysis of respective PDT responders showed that they were overrepresented within carriers of the 677T allele [175]. In a related study 90 Caucasian patients with neovascular AMD were subdivided in responder and nonresponder to Verteporfin PDT. Of six gene polymorphisms genotyped, thrombophilic factor V G1691A, factor XIII-A G185T, methionine synthase A2756G, methionine synthase reductase A66G, methylenetetrahydrofolate reductase C677T and prothrombin G20210A, the latter two were identified to be more prevalent within responders. Hyperfibrinolytic factor XIII-A G185T was clearly overrepresented in the nonresponder fraction [176,177].

These studies not only point towards the crucial involvement of blood clotting events in PDT action but also indicate a necessity to take pharmacogenetic results into account when formulating treatment guidelines and to improve the cost-effectiveness of such treatments.

PDT has also been shown to be able to control hemoptysis from hereditary telangiectasis in a case study [178]. Using PDT with DHE in a patient with a multi-year history of repeated embolo therapies, tracheostomies and ventilator dependence it was concluded that PDT causes thrombosis and may be used to control bleeding from small vessels. Another report addressed the utility of PDT in the presence of coagulopathy. A patient with superficial esophageal cancer with $\mathrm{HCV}$ related Childs $\mathrm{C}$ cirrhosis was treated with HPD (5 mg. kg ${ }^{-1}, 200 \mathrm{~J} . \mathrm{cm}$ per fiber, $\lambda=630 \mathrm{~nm}, 400 \mathrm{~mW}$ ) and after $4 \mathrm{~m}$ showed Barrett's epithelium but no carcinoma [179].

\section{Conclusion and Outlook}

As we have reviewed in this article, platelets appear to be a major cellular element targeted by PDT. However, the concept of targeting platelet associated processes and factors via PDT has some inherent problems. A major one related to the current quest to utilize "nano"molecular drug delivery systems for PDT [16]. This is the result of attempts to deliver larger amounts of PS selectively to the cell, e.g., in nanoaggregates such as liposomes, to use the enhanced permeability and retention (EPR) effect, which is primarily based on size, or to construct dual modality systems. However, negative effects such as hemolysis, platelet activation and aggregation, generation of reactive nitrogen and oxygen species, leucocyte activation and adhesion 
and complement activation have been described for nanocarriers aimed at the vascular system $[180,181,182,183]$. This problem arises from the fact that the nano-targeted vascular system contains large amounts of platelets near the vascular wall and the platelet activating effect of microparticles has been known for almost 50 years [184]. The in vivo effects can be complex and size, shape, hydrophobicity, material type, and surface charge of the nanoparticles modulate the clinical manifestations [160]. For a detailed review see Huang et al. [183]. As always there is also a bright side to this. It may be possible to design platelet-compatible nanocarriers [185].

Moreover, several studies have shown that Visudyne PDT can result in the extravasation of large molecules from blood vessels. As described above the magnitude of this effect depends on the length of the drug-light interval. This effect appears to be related to the inflammatory tissue response and the possibility exists to specifically use this effect for the local modulation of in vivo delivery of macromolecules [186]. For example, an increased uptake of liposomal formulations of doxorubicin was found in xenografted Colo26 tumor upon PDT [187].

Clearly a more detailed understanding of microvascular as well as platelet effects in PDT is necessary. The expanding knowledge on the effect of signaling substances and chemotherapeutic drugs on the regulation of these processes should led to the development of optimized treatment protocols once more translational in vivo and human studies are available.

\section{Acknowledgments}

This work was supported by grants from Science Foundation Ireland (SFI P.I. 09/IN.1/B2650 and P.I. 05/FE1/B862) and the Health Research Board (HRB Translational Research Award 2007 TRA/2007/11).

\section{References}

[1] Raab O. Über die Wirkung fluoreszierender Stoffe auf Infusorien. Z Biologie (München) 1990; 39:524-546.

[2] Finsen NR. Die Bekämpfung des Lupus vulgaris. Gustav Fischer: Jena, 1903.

[3] Meyer-Betz F. Untersuchungen über die biologische (photodynamische) Wirkung des Hämatoporphyrins und anderer Derivative des Blut- und Gallenfarbstoffs. Dtsch Arch Klin Med 1913; 112:476-503.

[4] Menke JF. Photodynamic action on normal and malignant cells in vitro. Carnegie Inst Contr Embryol 1935; 25:145-160.

[5] Stilwell EF, The photodynamic action of neutral red on embryonic chick cells grown in vitro. Anat Rec 1942; 84:193-212.

[6] Lewis MR. The injurious effect of light upon dividing cells in tissue cultures containing fluorescent substances. Anat Rec 1945; 91:199-207.

[7] Schwartz SK, Absolon K, Vermund H. Some relationships of porphyrins, X-rays and tumors. U Minn Med Bull 1955; 27:7-8.

[8] Lipson RL, Baldes EJ, Gray MJ. Hematoporphyrin derivative for detection and management of cancer. Cancer 1967; 20:2255-2257. 
[9] Dougherty TJ, Gomer CJ, Henderson BW, Jori G, Kessel D, Korbelik M, Moan J, Peng Q. Photodynamic Therapy. J Natl Cancer Inst 1998; 90:889-905.

[10] MacDonald IJ, Dougherty TJ. Basic principles of photodynamic therapy. J Porphyrins Phthalocyanines 2001; 5:105-129.

[11] Figge FHJ, Weiland GS, Manganiello LOJ. Cancer detection and therapy Affinity of neoplastic, embryonic, and traumatized tissues for porphyrins and metalloporphyrins. Proc Soc Exp Biol Med 1948; 68:640-641.

[12] DeRosa MC, Crutchley RJ. Photosensitized singlet oxygen and its applications. Coord Chem Rev 2002; 233:351-371.

[13] Ochsner M. Photophysical and photobiological processes in the photodynamic therapy of tumours. J Photochem Photobiol B Biol 1997; 39:1-18.

[14] Brown SB, Brown EA, Walker I. The present and future role of photodynamic therapy in cancer treatment. Lancet Oncol 2004; 5:497-508.

[15] Dolmans DEJGJ, Fukumura D, Jain RK. Photodynamic therapy for cancer. Nature Rev Cancer 2003; 3:380-387.

[16] Paszko E, Ehrhardt C, Senge MO, Kelleher DP, Reynolds JV. Nanodrug applications in photodynamic therapy. Photodiagn Photodyn Ther 2011; 8:14-29.

[17] Wainwright M. Photodynamic therapy: the development of new photosensitisers. Anticancer Agents Med Chem 2008; 8:280-291.

[18] Garland MJ, Cassidy CM, Woolfson D, Donnelly RF. Designing photosensitizers for photodynamic therapy: strategies, challenges and promising developments. Fut Med Chem 2009; 1:667-691.

[19] Wainwright M. The development of phenothiazinium photosensitizers. Photodiagn Photodyn Ther 2005; 2:263-272.

[20] Agostinis P, Vantieghem A, Merlevede W, de Witte PAM. Hypericin in cancer treatment: more light on the way. Int J Biochem Cell Biol 2002; 34:221-241.

[21] Gomer CJ. Preclinical examination of 1st and 2nd generation photosensitizers used in photodynamic therapy. Photochem Photobiol 1991; 54:1093-1107.

[22] Kessel D. Hematoporphyrin and HPD - Photophysics, photochemistry and phototherapy. Photochem Photobiol 1984; 39:851-859.

[23] Bonnett R, White RD, Winfield UJ, Berenbaum MC. Hydroporphyrins of the meso-tetra(hydroxyphenyl)porphyrin series as tumor photosensitizers. Biochem $\mathrm{J}$ 1989; 261:277-280.

[24] Senge MO, Brandt JC. Lead Structures for Applications in Photodynamic Therapy - 3. Temoporfin (Foscan $®, 5,10,15,20$-Tetra(m-hydroxyphenyl)chlorin), a Second Generation Photosensitizer. Photochem Photobiol 2011; 87:12401296.

[25] Peng Q, Warlo T, Berg K, Moan J, Kongshaug M, Giercksky KE, Nesland JM. 5aminolevulinic acid-based photodynamic therapy - Clinical research and future challenges. Cancer 1997; 79:2282-2308.

[26] Bedwell J, MacRobert AJ, Phillips D, Bown SG. Fluorescence distribution and photodynamic effect of ALA-induced PP-IX in the DMH rat colonic tumor model. Br J Cancer 1992; 65:818-824.

[27] Bressler NM. Photodynamic therapy of subfoveal choroidal neovascularization in age-related macular degeneration with verteporfin - One-year results of 2 randomized clinical trials - TAP report 1. Arch Ophthalmol 1999; 117:1329-1345. 
[28] Miller JW, Walsh AW, Kramer M, Hasan T, Michaud N, Flotte TJ, Haimovici R, Gradoudas ES. Photodynamic therapy of experimental choroidal neovascularization using lipoprotein-delivered benzoporphyrin. Arch Ophthalmol 1995; 113:810-818.

[29] Rosenfeld PF, Brown DM, Heier JS, Boyer DS, Kaiser PK, Chung CY, Kim RY. Ranibizumab for neovascular age-related macular degeneration. New Engl J Med 2006; 355:1419-1431.

[30] Campa C, Costagliola C, Incorvaia C, Sheridan C, Semeraro F, De Nadai K, Sebastiani A, Parmeggiani F. InflammatoryMediators and Angiogenic Factors in Choroidal Neovascularization: Pathogenetic Interactions and Therapeutic Implications. Med Inflamm 2010; Art. no. 546826, 14 pp.

[31] Ethirajan M, Chen YH, Joshi P, Pandey RK. The role of porphyrin chemistry in tumor imaging and photodynamic therapy. Chem Soc Rev 2011; 40:340-362.

[32] Huang Z, Chen Q, Luck D, Beckers J, Wilson BC, Trncic N, Larue SM, Blanc D, Hetzel FW. Studies of a vascular-acting photosensitizer, Pdbacteriopheophorbide (Tookad), in normal canine prostate and spontaneous canine prostate cancer. Lasers Surg Med 2005; 36:390-397.

[33] Koudinova NV, Pinthus JH, Brandis A, Brenner O, Bendel P, Ramon J, Eshhar Z, Scherz A, Salomon Y. Photodynamic therapy with Pd-bacteriopheophorbide (TOOKAD): Successful in vivo treatment of human prostatic small cell carcinoma xenografts. Int J Cancer 2003; 104: 782-789.

[34] Moore JV, West CML, Whitehurst C. The biology of photodynamic therapy. Phys Med Biol 1997; 42:913-955.

[35] Gomer CJ, Rucker N, Murphree AL. Differential cell photosensitivity following porphyrin photodynamic therapy. Cancer Res 1988; 48:4539-4542.

[36] Almeida RD, Manadas BJ, Carvalho AP, Duarte CB. Intracellular signaling mechanisms in photodynamic therapy. Biochim. Biophys. Acta 2004; 1704:59-86.

[37] Radomski MW, Radomski AS. Regulation of blood cell function by the endothelial cells. In: Vascular endothelium in human physiology and pathophysiology, eds. P. Vallance and D. Webb, Harwood Academic Publishers 2000, pp. 95-106.

[38] Radomski MW, Palmer RMJ, Moncada S. The antiaggregating properties of vascular endothelium: interactions between prostacyclin and nitric oxide. $\mathrm{Br} J$ Pharmacol 1987; 92:639-647.

[39] Radomski MW, Palmer RM, Moncada S. Endogenous nitric oxide inhibits human platelet adhesion to vascular endothelium. Lancet 1987; 2:1057-1058.

[40] Radomski MW, Palmer RMJ, Moncada S. An L-arginine/nitric oxide pathway present in human regulates aggregation. Proc Natl Acad Sci USA 1990; 87:5193-5197.

[41] Santos-Martinez MJ, Medina C, Jurasz P, Radomski MW. Metalloproteinases in platelet function. Thromb Res 2008; 121:535-542.

[42] Radomski MW, Salas E. Nitric oxide:mediator, modulator and factor of injury: its role in the pathogenesis of atherosclerosis. Atherosclerosis 1995; 118:S69-S80.

[43] Cerletti C, Tamburrelli C, Izzi B, Gianfagna F. de Gaetano G. Platelet-leukocyte interactions in thrombosis. Thromb Res 2012; 129:263-266. 
[44] Jurasz P, Alonso-Escolano D, Radomski MW. Platelet-cancer interactions: mechanisms and pharmacology of tumour cell-induced platelet aggregation. $\mathrm{Br} \mathrm{J}$ Pharmacol 2004; 143:819-826.

[45] Jurasz P, Sawicki G, Duszyk M, Sawicka J, Miranda C, Mayers I, Radomski MW. Matrix metalloproteinase-2 in tumour-cell induced platelet aggregation: Regulation by NO. Cancer Res 2001; 61:376-382.

[46] Jurasz P, Alonso D, Castro-Blanco S, Murad F, Radomski MW. Generation and role of angiostatin in human platelets. Blood 2003; 102:3217-3223.

[47] Alonso-Escolano D, Medina C, Cieslik K, Radomski A, Jurasz P, SantosMartinez MJ, Jiffar T, Ruvolo P, Radomski MW. PKC $\delta$ mediates platelet-induced breast cancer cell invasión. J Pharmacol Exp Ther 2006; 318:372-380.

[48] Radziwon-Balicka A, Medina C, O'Driscoll L, Bazou D, Inkielewicz-Stepniak I, Radomski A, Treumann A, Jow H, Radomski MW. Platelets increase survival of adenocarcinoma cells challenged with antcancer drugs: mechanisms and implications for chemoresistance. $\mathrm{Br} \mathrm{J}$ Pharmacol 2012; doi: 10.1111/j.14765381.2012.01991.x. [Epub ahead of print.]

[49] Marcus AJ, Broekman MJ, Pinsky DJ. Cox inhibitors and thromboregulation. New England J Med 2002; 347:1025-1026.

[50] Palacio S, Hart RG, Pearce LA, Benavente OR. Effect of addition of clopidogrel to aspirin on mortality: systematic review of randomized trials. Stroke 2012; 43:2157-2162.

[51] Michelson AD. Advances in antiplatelet therapy. Hematology Am Soc Hematol Educ Program 2011; 2011:62-69.

[52] Rothwell PM, Price JF, Fowkes FGR, Anchetti A, Rancaglioni MC, Tagnoni G, Lee R, Belch JFF, Wilson M, Mehta Z, Maede TW. Short term effects of daily aspirin on cancer mortality, and non-vascular death: analysis of the time course of risks and benefits in 51 randomised controlled trials. Lancet 2012; 379:16021612.

[53] Dickson RC, Doery JC, Lewis AF. Ultraviolet light: a new stimulus for the induction of platelet aggregation. Science 1971; 172:1140-1142.

[54] Povlishock JT, Rosenblum WI, Sholley MM, Wei EP. An Ultrastructural Analysis of Endothelial Change Paralleling Platelet Aggregation in a Light/Dye Model of Microvascular Insult. Am J Pathol 1983; 110:148-160.

[55] Arfors KE, Cockburn JS, Gross JF. Measurement of growth rate of laser-induced intravascular platelet aggregation and the influence of blood flow velocity. Microvasc Res 1976; 11:79-87.

[56] Weideman MP. Vascular reactions to laser in vivo. Microvasc Res 1974; 8:132138.

[57] Meinke M, Müller G, Helfmann J, Friebel M. Optical properties of platelets and blood plasma and their influence on the optical behavior of whole blood in the visible to near infrared wavelength range. J Biomed Opt 2007; 12: Art. no. 014024,

[58] Sikurova L, Balis P., Zvarik M. Penetration of laser light through red blood cell ghosts. J Photochem Photobiol B:Biol 2011; 103:230-233.

[59] Maurer HM, Haggins JC, Still WJ. Platelet injury during phototherapy. Am J Hematol 1976; 1:89-96. 
[60] Maurer HM, Fratkin M, McWilliams NB, Kirkpatrick B, Draper D, Haggins JC, Hunter CR. Effects of phototherapy on platelet counts in low-birthweight infants and on platelet production and life span in rabbits. Pediatrics 1976; 57:506-512.

[61] Caldera R, Maynier M, Galiay JC, Georges P, Esmilaire L, Tortrat D, Badoual J. A study of side-effects of phototherapy. Ann Pediatr 1995; 42:29-36.

[62] Patricò G, Fichera A, Caltabiano L, Scuderi A, Sciacca F. [Platelet factor 4 levels in full-term newborns undergoing phototherapy]. Pediatr Med Chir 1989; 11:639641.

[63] Akisü M, Yilmaz D, Tüzün $S$, Kültüsay N. Antioxidant defense systems in newborns undergoing phototherapy. Indian J Pedatr 1999; 66:651-655.

[64] Monsef A, Eghbalian F. Does conventional phototherapy have any effect on platelet count in full term neonates with indirect hyperbilirubinemia? Health 2011; 3:709-711.

[65] Zieve PD, Solomon HM, Krevans JR. The Effect of Hematoporphyrin and Light on Human Platelets. I. MORPHOLOGIC, FUNCTIONAL, AND BIOCHEMICAL CHANGES. J Cell Physiol 1966; 67:271-280.

[66] Solomon HM, Zieve PD, Krevans JR. The Effect of Hematoporphyrin and Light on Human Platelets. II. UPTAKE OF HEMATOPORPHYRIN. J Cell Physiol 1966; 67:281-284.

[67] Zieve PD, Solomon HM. The Effect of Hematoporphyrin and Light on Human Platelets. III. RELEASE OF POTASSIUM AND ACID PHOSPHATASE. J Cell Physiol 1966; 68:109-111.

[68] Zhou C, Chi S, Deng J, Zhang H, Liang J. Effect of photodynamic therapy on mouse platelets. Proc SPIE 1993;1881:60-66.

[69] Moor ACE, Lagerberg JWM, Tijssen K, Foley S, Truscott TG, Kochevar IE, Brand A, Dubbelman TMAR, VanSteveninch J. In vitro Fluence Rate Effects in Photodynamic Reactions with AIPcS4 as Sensitizer. Photochem Photobiol 1997; 66:860-865.

[70] Henderson BW, Owczarczak B, Sweeney J, Gessner T. Effects of photodynamic treatment of platelets or endothelials cells in vitro on platelet aggregation. Photochem Photobiol 1992; 56:513-521.

[71] Henderson BW, Donovan JM. Release of prostaglandin E2 from cells by photodynamic treatment in vitro. Cancer Res. 1989; 49:6896-6900.

[72] Harris F, Chatfield LK, Phoenix DA. Phenothiazinium based photosensitisers Photodynamic agents with a multiplicity of cellular targets and clinical applications. Curr Drug Targ 2005; 6:615-627.

[73] Adili F, Statius van Eps RG, Karp SJ, Watkins MT, LaMuraglia GM. Differential modulation of vascular endothelial and smooth muscle cell function by photodynamic therapy of extracellular matrix: novel insights into radical-mediated prevention of intimal hyperplasia. J Vasc Surg 1996; 23:698-705.

[74] Fungaloi P, Statius van Eps RG, Wu YP, Blankensteijn J, de Groot P, van Urk H, van Hillegersberg R, LaMuraglia G. Platelet Adhesion to Photodynamic Therapytreated Extracellular Matrix Proteins. Photochem Photobiol 2002; 75:412-417.

[75] Stief TW. Regulation of Hemostasis by Singlet-Oxygen $\left({ }^{1} \Delta \mathrm{O}_{2}{ }^{*}\right)$. Curr Vasc Pharmacol 2004; 2:357-362. 
[76] Kobayashi W, Liu Q, Matsumiya T, Nakagawa H, Yoshida H, Imaizumi T, Satoh $\mathrm{K}$, Kimura $\mathrm{H}$. Photodynamic therapy upregulates expression of Mac-1 and generation of leukotriene B4 by human polymorphonuclear leukocytes. Oral Oncol 2004; 40:506-510.

[77] Olivier D, Douillard S, Lhommeau I, Bigot E, Patrice T. Secondary oxidants in human serum exposed to singlet oxygen: the influence of hemolysis. Photochem Photobiol Sci 2009; 8:1476-1486.

[78] Lee DK, Choi Y, Shon S-M, Schellingerhout D, Park JE, Kim D-E. Atorvastatin and clopidogrel interfere with photosensitization in vitro. Photochem Photobiol Sci 2011; 10:1587-1592.

[79] Yao Y, Wolverton YY, Zhang Q, Marathe GK, Al-Hassani M, Konger RL, Travers JB. Ultraviolet $B$ radiation generated platelet-activating factor receptor agonist formation involves EGF-R-mediated reactive oxygen species. J Immunol 2009; 182:2842-2848.

[80] Dai T, Huang Y-Y, Hamblin MR. Photodynamic therapy for localized infectionsState of the art. Photodiagn Photodyn Ther 2009; 6:170-188.

[81] Wainwright $M$. The emerging chemistry of blood disinfection. Chem Soc Rev 2002; 31:126-136.

[82] Mohr H, Redecker-Klein A. Inactivation of pathogens in platelet concentrates by using a two-step procedure. Vox Sang 2003; 84:96-104.

[83] Ben-Hur E, Geacintov NE, Studamire B, Kenney ME, Horowitz B. The effect of irradiance on virus sterilization and photodynamic damage in red blood cells sensitized by phthalocyanines. Photochem Photobiol 1995; 61:190-195.

[84] Ben-Hur E, Barshtein G, Chen S, Yedgar S. Photodynamic treatment of red blood cell concentrates for virus inactivation enhances red blood cell aggregation: protection with antioxidants. Photochem Photobiol 1997; 66:509512.

[85] Wagner SJ, Skripchenko A, Robinette D, Mallory DA, Cincotta L. Preservation of red cell properties after virucidal phototreatment with dimethylmethylene blue. Transfusion 1998; 38:729-737.

[86] Besselink GA, van Engelenburg FA, Ebbing IG, Hilarius PM, de Korte D, Verhoeven AJ. Additive effects of dipyramidole and Trolox in protecting human red cells during photodynamic treatment. Vox Sang 2003; 85:25-30.

[87] Trannoy L, Roelen D, Koekkoek K, Brand A. Impact of Photodynamic Treatment with Meso-substituted Porphyrin on the Immunomodulatory Capacity of White Blood Cell-containing Red Blood Cell Products. Photochem Photobiol 2010; 86:223-230.

[88] Fingar $\mathrm{VH}$. Vascular effects of photodynamic therapy. J Clin Laser Med Surg 1996; 14:323-328.

[89] Krammer B. Vascular effects of photodynamic therapy. Anticancer Res 2001; 21:4271-4277.

[90] Nowis D, Stokłosa T, Legat M, Issat T, Jakóbisiak M, Gołab J. The influence of photodynamic therapy on the immune response. Photodiagn Photodyn Ther 2005; 2:283-298.

[91] Castano AP, Mroz, Hamblin MR. Photodynamic therapy and anti-tumour immunity. Nature Rev Cancer 2006; 6:535-545. 
[92] Frost GA, Halliday GM, Damian DL. Photodynamic Therapy-Induced Immunosuppression in Humans Is Prevented by Reducing the Rate of Light Delivery. J Invest Dermatol 2011; 131:962-968.

[93] Cecic, I, Korbelik M. Mediators of peripheral blood neutrophilia induced by photodynamic therapy of solid tumors. Cancer Lett 2002; 183:43-51.

[94] van den Bergh $\mathrm{H}$. Photodynamic therapy of age-related macular degeneration: History and principles. Sem Ophthalmol 2001; 16:181-200.

[95] Bhuvaneswari R, Gan YY, Lucky SS, Chin WWL, Ali SM, Soo KC, Olivo M. Molecular profiling of angiogenesis in hypericin mediated photodynamic therapy. Mol Cancer 2008; 7: Art. no. 56, 14 pp.

[96] Jiang J, Goel R, Schmechel S, Vercellotti G, Forster C, Bischof J. Preconditioning cryosurgery: Cellular and molecular mechanisms and dynamics of TNF- $\alpha$ enhanced cryotherapy in an in vivo prostate cancer model system. Cryobiology 2010; 61:280-288.

[97] Debefve E, Mithieux F, Percentes JY, Wang Y, Cheng C, Schaefer SC, Ruffieux C, Ballini J-P, Gonzalez M, van den Bergh H, Ris H-B, Lehr H-A, Krueger T. Leukocyte-endothelial cell interaction is necessary for photodynamic therapy induced vascular permeabilization. Lasers Surg Med 2011; 43:696-704.

[98] Bil J, Wlodarski P, Winiarska M, Kurzaj Z, Issat T, Jozkowicz A, Wegiel B, Dulak J, Golab J. Photodynamic therapy-driven induction of suicide cytosine deaminase gene. Cancer Lett 2010; 290:216-222.

[99] Ji Z, Yang G, Shahzidi S, Tkacz-Stachowska K, Suo Z, Nesland JM, Peng Q. Induction of hypoxia-inducible factor-1a overexpression by cobalt chloride enhances cellular resistance to photodynamic therapy. Cancer Lett 2006; 244:182-189.

[100] Fan S, Qiu H, Huang H, Gu Y, Zeng J. Effects of Photodynamic Therapy Using Hematoporphyrin Monomethyl Ether on Experimental Choroidal Neovascularization. Photochem Photobiol 2010; 86:972-980.

[101] Schlötzer-Schrehardt U, Viestenz A, Naumann GOH, Laqua H, Michels S, Schmidt-Erfurth U. Dose-related structural effects of photodynamic therapy on choroidal and retinal structures of human eyes. Graefe's Arch Clin Exp Ophthalmol 2002; 240:748-757.

[102] Schmidt-Erfurth U, Michels S, Indorf L, Eggers R, Birngruber R. Mechanism of Photodynamic Occlusion Using Liposomal Zn(II)-Phtalocyanine. Curr Eye Res 2005; 30:601-612.

[103] Ghazi NG, Jabbour NM, De La Cruz ZC, Green WR. Clinicopathologic studies of age-related macular degeneration with classic subfoveal choroidal neovascularization treated with photodynamic therapy. Retina 2001; 21:478-486.

[104] Debefve E, Pegaz B, van den Bergh H, Wagnières G, Lange N, Ballini J-P. Video monitoring of neovessel occlusion induced by photodynamic therapy with verteporfin (Visudyne ${ }^{\circledR}$ ), in the CAM model. Angiogenesis 2008; 11:235-243.

[105] Nowak-Sliwinska P, van Beijnum JR, van Berkel M, van den Bergh H, Griffioen AW. Vascular regrowth following photodynamic therapy in the chicken embryo chorioallantoic membrane. Angiogenesis 2010; 13:281-292.

[106] Shimizu K, Oku N. Cancer Anti-angiogenic Therapy. Biol Pharm Bull 2004; 27:599-605. 
[107] Kurohane K, Tominaga A, Sato K, North JR, Namba T, Oku N. Photodynamic therapy targeted to tumor-induced angiogenic vessels. Cancer Lett 2001; 167:4956.

[108] Takeuchi Y, Ichikawa K, Yonezawa S, Kurohane K, Koishi T, Nango M, Namba $\mathrm{Y}$, Oku N. Intracellular target for photo sensitization in cancer antiangiogenic photodynamic therapy mediated by polycation liposome. J Contr Rel 2004; 97:231-240.

[109] Takeuchi Y, Kurohane K, Ichikawa K, Yonezawa S, Nango M, Oku N. Induction of intensive tumor suppression by antiangiogenic photodynamic therapy using polycation-modified liposomal photosensitizer. Cancer 2003; 97:2027-2034.

[110] Deininger MH, Weinschenk T, Morgalla MH, Meyermann R, Schluesener HJ. Release of regulators of angiogenesis following Hypocrellin-A and $-B$ photodynamic therapy of human brain tumor cells. Biochem Biophys Res Commun 2002; 298:520-530.

[111] Browder T, Folkman J, Pirie-Shepherd S. The hemostatic system as a regulator of angiogenesis. J Biol Chem 2000; 275:1521-1524.

[112] Jurasz P, Santos-Martinez MJ, Radomska A, Radomski MW. Generation of platelet angiostatin mediated by urokinase plasminogen activator: effects of angiogenesis. J Thromb Haemost 2006; 4:1095-1106.

[113] Bhuvaneswari R, Yuen GY, Chee SK, Olivio M. Antiangiogenesis agents avastin and erbitux enhance the efficacy of photodynamic therapy in a murine bladder tumor model. Lasers Surg Med 2011; 43:651-662.

[114] Min SK, Kenagy RD, Clowes AW. Induction of vascular atrophy as a novel approach to treating restenosis. A review. J Vasc Surg 2008; 47:662-670.

[115] Stone GW, Ellis SG, Cox DA, Hermiller J, O'Shaughnessy C, Mann JT, Turco M, Caputo R, Bergin P, Greenberg J, Popma JJ, Russell ME. A polymer-based, paclitaxel-eluting stent in patients with coronary artery disease. New England $\mathrm{J}$ Med 2004; 350:221-231.

[116] van der Hoeven BL, Pires NMM, Warda HM, Oemrawsingh PV, van Vlijmen BJM, Quax PHA, Schalij MJ, van der Wall EE, Jukema JW. Drug-eluting stents: results, promises and problems. Int J Cardiol 2005; 99:9-17.

[117] Magaraggia M, Marigo L, Pagnan A, Jori G, Visonà A. Porphyrin-Photosensitized Processes: Their Applications in the Prevention of Arterial Restenosis. Cardiovasc Hematol Agents Med Chem 2007; 5:278-288.

[118] Yamaguchi A, Woodburn KW, Hayase M, Hoyt G, Robbins RC. Photodynamic therapy with motexafin lutetium (Lu-Tex) reduces experimental graft coronary artery disease. Transplantation 2001; 71:1526-1532.

[119] Heckenkamp J, Leszczynski D, Schiereck J, Kung J, LaMuraglia GM. Different effects of photodynamic therapy and $y$-irradiation on vascular smooth muscle cells and matrix: Implications for inhibiting restenosis. Arterioscl Thromb Vasc Biol 1999; 19:2154-2161.

[120] Heckenkamp J, Gawenda M, Overhaus M, Brunkwall J. Systemic and local mechanisms of vascular photo-dynamic therapy to prevent restenosis. Langenbeck's Arch Surg 2001; 386:463-464.

[121] Waksman R, Robinson KA, Crocker IR, Wang C, Gravanis MB, Cipolla GD, Hillstead RA, King SB. Intracoronary low-dose beta-irradiation inhibits neointima 
formation after coronary artery balloon injury in the swine restenosis model. Circulation 1995; 92:3025-3031.

[122] Rockson SG, Lorenz DP, Cheong WF, Woodburn KW. Photoangioplasty: An emerging clinical cardiovascular role for photodynamic therapy. Circulation 2000; 102:591-596.

[123] Yamaguchi A, Woodburn KW, Hayase M, Robbins RC. Reduction of vein graft disease using photodynamic therapy with motexafin lutetium in a rodent isograft model. Circulation 2000; 102:III275-III280.

[124] Adili F, Scholz T, Hille M, Heckenkamp J, Barth S, Engert A, Schmitz-Rixen T. Photodynamic Therapy Mediated Induction of Accelerated Re-endothelialisation Following Injury to the Arterial Wall: Implications for the Prevention of Postinterventional Restenosis. Eur J Vasc Endovasc Surg 2002; 24:166-175.

[125] Waksman R, Leitch IM, Roessler J, Yazdi H, Seabron R, Tio F, Scott RW, Grove RI, Rychnovsky S, Robinson B, Pakala R, Cheneau E. Intracoronary photodynamic therapy reduces neointimal growth without suppressing reendothelialisation in a porcine model. Heart 2006; 92:1138-1144.

[126] Heckenkamp J, Aleksic M, Gawenda M, Breuer S, Brabender J, Mahdavi A, Aydin F, Brunkwall JS. Modulation of Human Adventitial Fibroblast Function by Photodynamic Therapy of Collagen Matrix. Eur J Endovasc Surg 2004; 28:651659.

[127] Fingar VH, Taber SW, Haydon PS, Harrison LT, Kempf SJ, Wieman TJ. Vascular damage after photodynamic therapy of solid tumors: A view and comparison of effect in pre-clinical and clinical models at the University of Louisville. In Vivo 2000; 14:93-100.

[128] Menon C, Kutney SN, Lehr SC, Hendren SK, Busch TM, Hahn SM, Fraker DL. Vascularity and Uptake of Photosensitizer in Small Human Tumor Nodules: Implications for Intraperitoneal Photodynamic Therapy. Clin Cancer Res 2001; 7:3904-3911.

[129] Star WM, Marijnissen HPA, van den Berg-Blok AE, Versteeg JAC. Destruction of rat mammary tumor and normal tissue microcirculation by hematoporphyrin derivative photoradiation observed in vivo in sandwich observation chambers. Cancer Res. 1986; 46: 2532-2540.

[130] Reed MWR, Wieman TJ, Schuschke DA, Tseng MT, Miller FN. A comparison of the effects of photodynamic therapy on normal and tumor blood vessels in the rat microcirculation. Radiation Res 1989; 119:542-552.

[131] Sacks T, Moldow CF, Craddock PR, Bowers TK, Jacob HS. Oxygen radicals mediated endothelial cell damage by complement stimulated granulocytes. J Clin Invest 1978; 61:1161-1167.

[132] Reed MWR, Miller FN, Wieman TJ, Tseng MT, Pietsch CG. The effect of photodynamic therapy on the microcirculation. J Surg Res 1988; 45:452-459.

[133] Verheij M, Dewit LG, Boomgaard MN, Brinkman HJ, van Mourik JA. Ionizing radiation enhances platelet adhesion to the extracellular matrix of human endothelial cells by an increase in the release of von Willebrand factor. Radiat Res 1994; 137:202-207. 
[134] De Vree W, Fontijne-Dorsman ANRD, Koster JF, Sluiter W. Photodynamic treatment of human endothelial cells promotes the adherence of neutrophils in vitro. Br J Cancer 1996; 73:1335-1340.

[135] De Vree WJA, Essers MC, De Bruijn HS, Star WM, Koster JF, Sluiter W. Evidence for an important role of neutrophils in the efficacy of photodynamic therapy in vivo. Cancer Res 1996; 56:2908-2911.

[136] Strauss WSL, Sailer R, Schneckenburger H, Akgün N, Gottfried V, Chetwer L, Kimel S. Photodynamic efficacy of naturally occurring porphyrins in endothelial cells in vitro and microvasculature in vivo. J Photochem Photobiol B:Biol 1997; 39:176-184.

[137] Liu DL, Svanberg K, Wang I, Andersson-Engels S, Svanberg S. Laser Doppler Perfusion Imaging: New Technique for Determination of Perfusion and Reperfusion of Splanchnic Organs and Tumor Tissue. Lasers Surg Med 1997; 20:473-479.

[138] Tibbitts J, Fike JR, Lamborn KR, Bollen AW, Kahl SB. Toxicology of a boronated porphyrin in dogs. Photochem Photobiol 1999; 69:587-594.

[139] Shibuya H, Aizawa K, Okunaka T, Konaka C, Saito K, Kato H. Acute microvascular response to photodynamic therapy with mono-L- aspartyl chlorin e6 and a diode laser: Observation under modified operation microscope. J Tokyo Med Univ 1999; 57:136-144.

[140] Yamamoto Y, Shibuya H, Okunaka T, Aizawa K, Kato H. Fibrin plugging as a cause of microcirculatory occlusion during photodynamic therapy. Lasers Med Surg 1999; 14:129-135.

[141] Statius Van Eps RG, Adili F, Watkin MT, Anderson RR, LaMuraglia GM. Photodynamic therapy of extracellular matrix stimulates endothelial cell growth by inactivation of matrix-associated transforming growth factor- $\beta$. Lab Invest 1997; 76:257-266.

[142] Statius Van Eps RG, Mark LL, Schiereck J, LaMuaglia M. Photodynamic therapy inhibits the injury-induced fibrotic response of vascular smooth muscle cells. Eur J Vasc Endovasc Surg 1999; 18:417-423.

[143] Heckenkamp J, Adili F, Kishimoto J, Koch M, LaMuraglia GM. Local photodynamic action of methylene blue favorably modulates the postinterventional vascular wound healing response. J Vasc Surg 2000; 31:11681177.

[144] Bechet D, Tirand L, Faivre B, Plénat F, Bonnet C, Bastogne T, Frochot C, Guillemin F, Harberi-Heyob M. Neuropilin-1 Targeting Photosensitization-Induced Early Stages of Thrombosis via Tissue Factor Release. Pharmaceut Res 2010; 27:468-479.

[145] Mak NK, Kok TW, Wong RNS, Lam SW, Lau YK, Leung WN, Cheung NH, Huang DP, Yeung LL, Chang CK. Photodynamic activities of sulfonamide derivatives of porphycene on nasopharyngeal carcinoma cells. J Biomed Sci 2003; 10:418-429.

[146] Casas A, Di Venosa G, Vanzulli S, Perotti C, Mamome L, Rodriguez L, Simian M, Juarranz A, Pontiggia O, Hasan T, Batlle A. Decreased metastatic phenotype in cells resistant to aminolevulinic acid-photodynamic therapy. Cancer Lett 2008; 271: 342-351. 
[147] Peng C-L, Lai P-S, Lin F-H, Wu SY-H, Shieh M-J. Dual chemotherapy and photodynamic therapy in an HT-29 human colon cancer xenograft model using SN-38-loaded chlorin-core star block copolymer micelles. Biomaterials 2009; 30:3614-3625.

[148] Fingar VH, Wieman TJ, Haydon PS. The Effects of Thrombocytopenia on Vessel Stasis and Macromolecular Leakage after Photodynamic Therapy Using Photofrin. Photochem Photobiol 1997; 66:513-517.

[149] Dolmas DEJGJ, Kadambi A, Hill JS, Waters CA, Robinson BC, Walker JP, Fukumura D, Jain RK. Vascular accumulation of a novel photosensitizer, MV6401, causes selective thrombosis in tumor vessels after photodynamic therapy. Cancer Res 2002; 62:2151-2156.

[150] Khurana M, Moriyama EH, Mariamillai A, Wilson BC. Intravital high-resolution optical imaging of individual vessel response to photodynamic treatment. $J$ Biomed Opt 2008; 13: Art. no. 040502, 3pp.

[151] Fingar VH, Wieman TJ, Doak KW. Role of thromboxane and prostacyclin release on photodynamic therapy-induced tumor destruction. Cancer Res 1990; 50:25992603.

[152] Fingar VH, Wieman TJ. Studies on the mechanism of photodynamic therapy induced tumor destruction. Proc SPIE 1990; 1203:168-177.

[153] Reed MWR, Schuschke DA, Miller FN. Prostanoid antagonists inhibit the response of the microcirculation to 'early' photodynamic therapy. Radiat Res 1991; 127:292-296.

[154] Fingar VH, Siegel KA, Wieman TJ, Doak KW. The effects of thromboxane inhibitors on the microvascular and tumor response to photodynamic therapy. Photochem Photobiol 1993; 58:393-399.

[155] Stern SJ, Craig JR, Flock S, Small S. Effect of aspirin on photodynamic therapy utilizing chloroaluminum sulfonated phthalocyanine (CASP). Lasers Surg Med 1992; 12:494-499.

[156] Debefve E, Pegaz B, Ballini J-P, Konan YN, van den Bergh H. Combination therapy using aspirin-enhanced photodynamic selective drug delivery. Vasc Pharmacol 2007; 46:171-180.

[157] Ranchod TM, Guercio JR, Ying GS, Brucker AJ, Stoltz RA. Effect of aspirin therapy on photodynamic therapy with verteporfin for choroidal neovascularization. Retina 2008; 28:711-716.

[158] Löw U, Kohlhof JK, Ruprecht KW. Wirkt sich Acetylsalicylsäure negativ auf die photodynamische Therapie aus? Ophthalmologe 2006; 103:204-208.

[159] Gilissen MJ, Van de Merbel-de Wit LEA, Star MW, Koster JF, Sluiter W. Effect of photodynamic therapy on the endothelium-dependent relaxation of isolated rat aortas. Cancer Res 1993; 53: 2548-2552.

[160] Breider MA, Lu X, Panjehpour M, Frazier DL. Cytokine modulation of endothelial cell sensitivity to photodynamic therapy. Lasers Surg Med 1993; 13, 305-311.

[161] Fanuel-Barret D, Patrice T, Foultier M-T, Vonarx-Coinsmann V, Robillard N, Lajat $\mathrm{Y}$. Influence of epidermal growth factor on photodynamic therapy of glioblastoma cells in vitro. Res Exp Med 1997; 197:219-233. 
[162] Tsai, JC, Hsiao YY, Teng LJ, Chen CT, Kao MC. Comparative study on the ALA photodynamic effects of human glioma and meningioma cells. Lasers Surg Med 1999; 24:296-305.

[163] Bhuvaneswari R, Gan YY-Y, Yee KKL, Soo KC, Olivio M. Effect of hypericinmediated photodynamic therapy onthe expression of vascular endothelial growth factor in human nasopharyngeal carcinoma. Int J Mol Med 2007; 20:421-428.

[164] Hendrix N, Dewaele M, Buytaert E, Marsboom G, Janssens S, Van Boven M, Vandenheede JR, de Witte P. Targeted inhibition of p38 MAPK suppresses tumor-associated endothelial cell migration in response to hypericin-based photodynamic therapy. Biochem Biophys Res Commun 2005; 337:928-935.

[165] Allen CM, Sharman WM, La Medeleine C, van Lier JE, Weber JM. Attenuation of photodynamically induced apoptosis by an RGD containing peptide. Photochem Photobiol Sci 2002; 1:246-254.

[166] Schieke S, von Montfort C, Buchczyk DP, Timmer A, Grether-Beck S, Krutmann J, Holbrook NJ, Klotz L-O. Singlet Oxygen-induced Attenuation of Growth Factor Signaling: Possible Role of Ceramides. Free Rad Res 2004; 38:729-737.

[167] Yang, L, Wei Y, Xing D, Chen Q. Increasing the Efficiency of Photodynamic Therapy by Improved Light Delivery and Oxygen Supply Using an Anticoagulant in a Solid Tumor Model. Lasers Surg Med 2010; 42:671-679.

[168] Fungaloi $P$, Waterman $P$, Nigri G, Statius-van Eps $R$, Sluiter W, van Urk $H$, LaMuraglia G. Photochemically Modulated Endothelial Cell Thrombogenicity via the Thrombomodulin-Tissue Pathway. Photochem Photobiol 2003; 78:475-480.

[169] Reeves KJ, Reed MWR, Brown NJ. Is nitric oxide important in photodynamic therapy? J Photochem Photobiol B:Biol 2009; 95:141-147.

[170] Korbelik M, Parkins CS, Shibuya H, Cecic I, Startford MR, Chaplin DJ. Nitric oxide production by tumour tissue: impact on the response to photodynamic therapy. Br J Cancer 2002; 82: 1835-1843.

[171] Henderson BW, Sitnik-Busch TM, Vaughan LA. Potentiation of photodynamic therapy antitumor activity in mice by nitric oxide synthase inhibition is fluence rate dependent. Photochem Photobiol 1990; 70:64-71.

[172] Korbelik M, Shibuya H, Cecic I. Relevance of nitric oxide to the response of tumours to photodynamic therapy. Proc SPIE 1998; 3247:98-105.

[173] Reeves KJ, Reed MWR, Brown NJ. The role of nitric oxide in the treatment of tumours with aminolaevulinic acid-induced photodynamic therapy. J Photochem Photobiol B:Biol 2010; 101:224-232.

[174] Parmeggiani F, Gemmati D, Costagliola C, Sebastini A, Incorvaia C. Predictive role of C677T MTHFR polymorphism in variable efficacy of photodynamic therapy for neovascular age-related macular degeneration. Pharmacogenomics 2009; 10:81-95.

[175] Parmeggiani F, Gemmati D, Costagliola C, Semeraro F, D'Angelo S, Perri P, Sebastiani A, Incorvaia C. Impact of Coagulation-Balance Gene Predictors on Efficacy of Photodynamic Therapy for Choroidal Neovascularization in Pathologic Myopia. Ophthalmology 2010; 117:517-523.

[176] Parmeggiani F, Costagliola C, Gemmati D, D'Angelo S, Perri P, Scapoli GL, Catozzi K, Federici F, Sebastiani A, Invorvaia C. Predictive role of coagulationbalance gene polymorphisms in the efficacy of photodynamic therapy with 
verteporfin for classic choroidal neovascularization secondary to age-related macular degeneration. Pharmacogen Genom 2007; 17:1039-1046.

[177] Parmeggiani F, Costagliola C, Gemmati D, D'Angelo S, Perri P, Campa C, Catozzi L, Federici F, Sebastiani A, Invorvaia C. Coagulation Gene Predictors of Photodynamic Therapy for Occult Choroidal Neovascularization in Age-Related Macular Degeneration. Invest Ophthalmol 2008; 49:3100-3106.

[178] McCaughan Jr JS, Hamley PC, Larosa JC, Thomas JH, Hicks WJ. Photodynamic therapy to control life-threatening hemorrhage from hereditary hemorrhagic telangiectasia. Lasers Surg Med 1996; 19:492-494.

[179] Wang KK, Norbash A, Geller A, Song MWK. Severe coagulopathy is not a contraindication for photodynamic therapy in a patient with Barretts esophageal carcinoma. Gastrointest Endosc 1996; 43:346.

[180] Radomski A, Jurasz P, Alonso-Escolano D, Drews M, Morandi M, Malinski T, Radomski MW. Nanoparticle-induced platelet aggregation and vascular thrombosis. Br J Pharmacol 2005; 146:882-893.

[181] Corbalan JJ, Medina C, Jacoby A, Malinski T, Radomski MW. Amorphous silica nanoparticles trigger nitric oxide/peroxynitrite imbalance in human endothelial cells - inflammatory and cytotoxicity effects. Int J Nanomed 2011; 6:1-15.

[182] Santos-Martinez MJ, Inkielewicz-Stepniak I, Medina C, Rahme K, D'Arcy D, Holmes JD, Zhang H, Radomski MW. The use of quartz crystal microbalance with dissipation for studying nanoparticle-induced platelet aggregation. Int $\mathrm{J}$ Nanomed 2012; 7:243-255.

[183] Huang RB, Mocherla SA, Heslinga MJ, Charoenphol P, Eniola-Adefeso O. Dynamic and cellular interactions of nanoparticles in vascular-targeted drug delivery (review). Mol Membr Biol 2010; 27:312-327.

[184] Movat HZ, Weiser WJ, Glynn MF, Mustard JF. Platelet phagocytosis and aggregation. J Cell Biol 1965; 27:531-543.

[185] Li X, Radomski A, Corrigan OI, Tajber L, De Sousa Menezes F, Endter S, Medina C, Radomski MW. The Platelet Compatibility of Poly(lactide-co-glycolide) (PLGA), Chitosan and PLGA- Chitosan Nanoparticles. Nanomedicine 2009; 4:735-746.

[186] Debefve E, Cheng C, Schaefer SC, Yan H, Ballini J-P, van den Bergh H, Lehr HA, Ruffieux C, Ris, H-B. Krueger T. Photodynamic therapy induces selective extravasation of macromolecules: Insights using intravital microscopy. J Photochem Photobiol B:Biol 2010; 98:69-76.

[187] Snyder JW, Greco WR, Bellnier DA, Vaughan K, Henderson BW. Photodynamic therapy: a means to enhanced drug delivery to tumors. Cancer Res 2003; 63:8126-8131. 